Published in final edited form as:

Biochem Pharmacol. 2018 March ; 149: 205-223. doi:10.1016/j.bcp.2018.01.042.

\title{
The dichotomous role of $\mathrm{H}_{2} \mathrm{~S}$ in cancer cell biology? Déjà vu all over again
}

\author{
Khosrow Kashfi ${ }^{1, *}$ \\ ${ }^{1}$ Department of Molecular, Cellular and Biomedical Sciences, Sophie Davis School of Biomedical \\ Education, City University of New York School of Medicine, New York, USA
}

\begin{abstract}
Nitric oxide (NO) a gaseous free radical is one of the ten smallest molecules found in nature, while hydrogen sulfide $\left(\mathrm{H}_{2} \mathrm{~S}\right)$ is a gas that bears the pungent smell of rotten eggs. Both are toxic yet they are gasotransmitters of physiological relevance. There appears to be an uncanny resemblance between the general actions of these two gasotransmitters in health and disease. The role of NO and $\mathrm{H}_{2} \mathrm{~S}$ in cancer has been quite perplexing, as both tumor promotion and inflammatory activities as well as anti-tumor and antiinflammatory properties have been described. These paradoxes have been explained for both gasotransmitters in terms of each having a dual or biphasic effect that is dependent on the local flux of each gas. In this review/commentary, I have discussed the major roles of $\mathrm{NO}$ and $\mathrm{H}_{2} \mathrm{~S}$ in carcinogenesis, evaluating their dual nature, focusing on the enzymes that contribute to this paradox and evaluate the pros and cons of inhibiting or inducing each of these enzymes.
\end{abstract}

\section{Graphical Abstract}

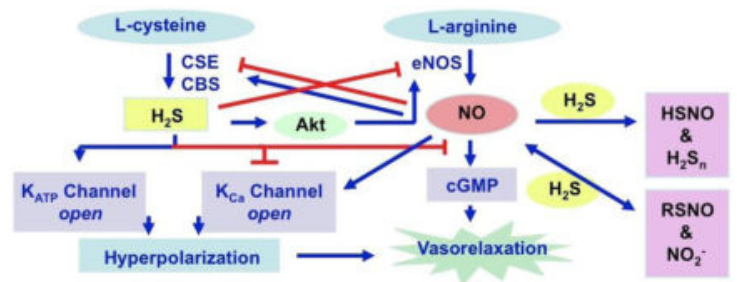

"Correspondence: Khosrow Kashfi, PhD, FRCS, Department of Molecular, Cellular, and Biomedical Sciences, City University of New York Medical School, 138th Street and Convent Avenue, New York, NY 10031, Tel: (212) 650-6641, Fax: (212) 650-7692, kashfi@med.cuny.edu.

\section{Conflict of interest}

KK holds an equity position in Avicenna Pharmaceuticals, Inc. to which NOSH-NSAIDs briefly described in this review have been licensed.

Authorship Contributions

$\mathrm{KK}$ - formulated the general concept of this review, researched the literature and wrote the manuscript.

Publisher's Disclaimer: This is a PDF file of an unedited manuscript that has been accepted for publication. As a service to our customers we are providing this early version of the manuscript. The manuscript will undergo copyediting, typesetting, and review of the resulting proof before it is published in its final citable form. Please note that during the production process errors may be discovered which could affect the content, and all legal disclaimers that apply to the journal pertain. 


\section{Key Works}

Nitric oxide; hydrogen sulfide; carcinogenesis; iNOS; CBS; CSE

\section{Introduction}

Nitric oxide (NO) a gaseous free radical is one of the ten smallest molecules found in nature, while hydrogen sulfide $\left(\mathrm{H}_{2} \mathrm{~S}\right)$ is a gas that bears the pungent smell of rotten eggs. Both are toxic yet are recognized as gasotransmitters that have multiple roles in normal physiology. For example, NO regulates vascular relaxation [1], controls inflammation by inhibiting NF$\kappa \mathrm{B}$ activation [2, 3], and suppresses expression of pro-inflammatory mediators in mast cells, macrophages and vascular smooth muscles [4-6]. NO regulates blood flow [1, 7], modulates platelet and leukocyte activation, adhesion, and aggregation [8]. The important role of NO in human biology was recognized in 1998 when the Nobel Prize in Physiology and Medicine was awarded to Robert F. Furchgott, Louis J. Ignarro, and Ferid Murad for establishing NO as a messenger molecule. Abe and Kimura established the physiological role of $\mathrm{H}_{2} \mathrm{~S}$ in a landmark study in 1996 showing it to be a neuromodulator [9]. However, it was Rui Wang in 2002 who proposed it to be the third gasotransmitter [10]; the first and second being NO and carbon monoxide, respectively. A quick inspection of the literature regarding the various aspects of $\mathrm{NO}$ and $\mathrm{H}_{2} \mathrm{~S}$ in health and disease leads one to conclude that there appears to be an uncanny resemblance between the general actions of these two gasotransmitters. For example, $\mathrm{H}_{2} \mathrm{~S}$ has also been shown to have vasorelaxant effects [11], and be protective in an animal model of myocardial ischemia-reperfusion injury [12]. Similarly to $\mathrm{NO}, \mathrm{H}_{2} \mathrm{~S}$ also inhibits leukocytes adherence to blood vessel walls [13] and appears to be intimately involved in reducing and promoting the resolution of inflammation [14].

The role of $\mathrm{NO}$ in cancer has been quite perplexing, as both tumor promotion and inflammatory activities as well as anti-tumor and antiinflammatory properties have been described [15-18]. Much like NO, the role of $\mathrm{H}_{2} \mathrm{~S}$ in inflammation, immunity, and cancer biology is also controversial, with some studies suggesting anti-inflammatory, anti-cancer effects, whereas others suggest a contribution to immune-mediated tissue injury and tumor promotion [19-25]. These paradoxes and controversies have been explained for both gasotransmitters in terms of each having a dual or biphasic effect that is dependent on the local flux of each gas $[16,18,24]$. In this commentary, I have discussed the major roles of $\mathrm{NO}$ and $\mathrm{H}_{2} \mathrm{~S}$ in carcinogenesis, evaluating their dual nature, focusing on the enzymes that contribute to this paradox and evaluate the pros and cons of inhibiting or inducing each of these enzymes. Although I do recognize that there is a contribution to be made by $\mathrm{CO}$, which can also play a role in cancer development/inhibition. Very briefly, CO is a colorless, odorless gas that is often referred to, as a "silent killer" because it is hard to detect and it's intoxication can be fatal. Despite its toxicity, CO has many physiological roles, for example, at low concentrations it relaxes smooth muscles and lowers the blood pressure [26]. The major endogenous source of $\mathrm{CO}$ in the body is breakdown of haem. Physiological degradation of haem occurs in a tightly controlled manner involving the enzyme haem oxygenase (HO) [27], of which there are three isozymes. HO-1, which is inducible and is stimulated in response to cellular stress [28-30]; HO-2, is constitutively expressed and its 
function is associated with neurotransmission and regulation of vascular tone [28, 31]; and HO-3, which is also constitutive but it's function is unknown as it does not possess any heme degrading activity $[32,33]$. Physiologically, similar to NO, CO activates guanylyl cyclase to produce cGMP but it is only about 1/80th as effective as NO [32]. Low concentrations of $\mathrm{CO}$ also activate $\mathrm{K}_{\mathrm{ATP}}$ channels and affect MAPK signaling pathways [34]. Similar to $\mathrm{NO}$ and $\mathrm{H}_{2} \mathrm{~S}, \mathrm{CO}$ also exhibits both pro and anti tumor activities, reviewed in [34]. Although not reviewed here, there is interaction between all three gasotransmitters. For example, $\mathrm{H}_{2} \mathrm{~S}$ may stimulate the expression of HO-1 through a signaling pathway depending on ERK and also through phosphorylation MAPK. The HO-1 then inhibits iNOS expression thus reducing NO production [35].

\section{NO and $\mathrm{H}_{2} \mathrm{~S}$ biosynthesis and metabolism}

NO is synthesized and released when L-arginine is metabolized by the enzyme nitric oxide synthase (NOS) [36, 37] of which there are three isoforms (Fig 1A). Neuronal (nNOS or NOS1) and endothelial (eNOS or NOS3) are constitutive (cNOS) and are calcium-dependent forms of the enzyme that are regulated by negative feedback [38], phosphorylation [39], and interaction with regulatory molecules [40]. cNOS produce low levels of NO over a short period of time, nanomolar concentrations for seconds or minutes, to regulate neural and vascular function respectively [41, 42]. In leukocyctes, NO derived from NOS may diffuse across the plasma membrane and cytoplasm. NO reacts with the active site of soluble guanylate cyclase (sGC) and produces cyclic GMP (cGMP). cGMP activates cGMPdependent Protein Kinase G (PKG), which phosphorylates multiple substrates [43]. In platelets, activation of the cGMP dependent kinase phosphorylates a variety of substrates, and is involved in platelet adhesion and aggregation [44]. In general, an increase in cGMP leads to smooth muscle relaxation, vasorelaxation and decrease of platelet aggregation [44, 45]. The third isoform (iNOS or NOS2), is calcium-independent, is regulated transcriptionally and is induced by inflammatory cytokines, oxidative stress, hypoxia, and various endotoxins $[46,47]$. iNOS produces micromolar levels of NO which may be for hours or days [48-50] and is involved in immune surveillance. In most cancers including colon, breast, gastric, glioma, leukemia, melanoma, ovarian, prostate, renal, and squamous carcinoma, it is this isoform that is highly expressed [34, 51-57]. However, nNOS has also been reported to be induced in glioma, melanoma, and myeloma; whereas eNOS is induced in pancreatic cancer, sarcoma, and renal cell carcinoma [34, 51, 53].

NO can also be produced through reduction of nitrite/nitrate under low oxygen conditions. In a paper published in 2003, it was shown that nitrite infusion in the human forearm increased forearm blood flow before and during exercise, in a NOS independent manner [58]. The mechanism for this increase in blood flow was suggested to be due to increases in $\mathrm{NO}$ levels as a result of nitrite reduction by deoxygenated $\mathrm{Hb}$ (deoxyHb). These results suggested that nitrite was indeed a bioavailable pool for $\mathrm{NO}$, and thus described a new physiological function for hemoglobin as a nitrite reductase, potentially contributing to hypoxic vasodilation. The biggest conceptual challenge to the notion that deoxyHb plays a major role in bioactivation of nitrite is that $\mathrm{NO}$ produced in the red blood cell would be rapidly scavenged by the dioxygenation reaction where $\mathrm{NO}$ reacts with oxygenated $\mathrm{Hb}$ $(\mathrm{OxyHb})$ to form methemoglobin (MetHb) and nitrate [59]. Considering the kinetics of this 
reaction, it becomes evident that very little NO that is made in the red blood cell can get out [60]. Several proposed mechanisms have been constructed to explain how nitrite-derived bioactivity can be exported from the red blood cell and these generally involve either a compartment model with submembrane localization of the reaction allowing for inefficient free $\mathrm{NO}$ escape, or the formation of another nitrogen oxide such as a nitrosothiol or $\mathrm{N}_{2} \mathrm{O}_{3}$ that can get out of the red blood cell and carry NO activity [61-65], (reviewed in [59]). The mechanism by which myoglobin $(\mathrm{Mb})$ would lead to nitrite bioactivation is the same as for $\mathrm{Hb}$ but the reaction was found to be substantially faster due to its lower heme redox potential [66]. Mb-mediated nitrite reduction has been reported to be important in both cardiomyocytes [67] and smooth muscle [68].

In general the oxidative pathway leads to modification of proteins by S-nitrosylation of cycteine residues [69-71] (Fig 1A). Such post translational modifications also affects transcriptional activity by alteration of DNA binding of the protein, for example as that seen for the transcription factor NF- $\kappa B$ which loses ability to bind DNA [72, 73]. Hypoxiainducible factor- 1 (HIF-1), estrogen receptor and NF- $B$arealsoredoxsensitive transcription factors that are regulated by S-nitrosylation [74]. S-nitrosylation may lead to either progression or inhibition of cancer [53]. S-nitrosylation of NF- $\mathrm{kB}$ and matrix metalloproteinase 9 (MMP9) promotes cell death whereas S-nitrosylation of caspase-3, caspase-9, and c-Jun N-terminal kinase prevents activity and inhibits apoptosis [73]. Death receptors were also found to be regulated in this way, for example nitrosylation of death receptor DR4 and Fas promotes apoptosis via the death-inducing signal complex [75, 76].

Peroxynitrite which is a strong oxidative and nitrosative agent is produced when NO reacts with oxygen radicals [53], this results in direct nitrosylation or nitrosation or nitration of signaling proteins. Nitrosative signaling in cancer cells is known to contribute to more proliferation, metastasis, and resistance to therapy and therefore, poor treatment outcomes [77]. On the other hand, apoptotic and necrotic cell death can occur by peroxynitrite via lipid peroxidation, cysteine oxidation, and by protein nitrosylation [78, 79]. Physiologically, endogenously generated NO diffuses through lumen of blood vessels and intracellular compartments and reacts with hemoglobin. This elimination pathway leads to the formation of nitrates and is most likely the major mechanism for NO catabolism [80].

Most, if not all of the biosynthesis of $\mathrm{H}_{2} \mathrm{~S}$ (Fig 1B) has been attributed to three enzymes [81], cystathionine $\beta$-synthase (CBS, EC 4.2.1.22), cystathionine $\gamma$-lyase (CSE aka CGL, EC 4.4.1.1) and the tandem enzymes cysteine aminotransferase (CAT, EC 2.6.1.3) and 3mercaptopyruvate sulfurtransferase (3-MST, EC 2.8.1.2). CBS, CSE, and CAT require pyridoxal $5^{\prime}$-phosphate (PLP) as a cofactor and use L-cysteine as substrate [82, 83], 3-MST produces $\mathrm{H}_{2} \mathrm{~S}$ using 3-mercaptopyruvate (3-MP), a metabolite of L-cysteine, which is produced by PLP- dependent CAT [84]. CBS, CSE and MST are constitutive enzymes and have different expression levels in different tissues and organs [34], although there is some recent evidence suggesting that CSE may be inducible [85]. Expression of CSE is modulated in diverse conditions such as inflammation mediated by tumor necrosis factor- $a$ (TNF-a) and lipopolysaccharides (LPS), metabolites such as glucocorticoids and glucose, as well as dietary restriction and endoplasmic reticulum (ER) stress [85-89]. $\mathrm{H}_{2} \mathrm{~S}$ can also be generated endogenously through nonenzymatic reduction of elemental sulfur in the blood 
[90] using reducing equivalents supplied through the glycolytic pathway [91] or from various storage forms of sulfur such as thiosulfate, thiocysteine and sulfite [92], (reviewed in [81] and also by Olson in this Special Issue, [93]).

Mammalian enzymes generally metabolize L-amino acids, however, $\mathrm{H}_{2} \mathrm{~S}$ can also be synthesized from D-cysteine [94, 95]. D-Cysteine is metabolized by the peroxisomal enzyme D-amino acid oxidase (DAO) [96] to 3-MP, which is a substrate for the mitochondrial enzyme 3- MST [84] in the production of $\mathrm{H}_{2} \mathrm{~S}$. The DAO/3-MST pathway is only active in the brain and the kidney because that is where DAO is localized. In the kidney, the production of $\mathrm{H}_{2} \mathrm{~S}$ from D-cysteine is 60 times higher than that from L-cysteine [97].

CBS expression levels have been reported to be higher in colon, breast, prostate, biliary tract, myeloma, renal, human malignant hyperthermia, and ovarian cancers compared to adjacent normal tissue or non-transformed cells [34, 98-103]. CSE has also been reported to have a high expression in colon, melanoma, lung, and prostate cancers [104-106]; while MST is reported to be high in glioma and melanoma [34, 104, 107].

Many cellular effects of $\mathrm{H}_{2} \mathrm{~S}$ are mediated by its interactions with membrane ion channels. Notably the ATP-sensitive potassium $\left(\mathrm{K}_{\mathrm{ATP}}\right.$ ) channel is targeted/opened by $\mathrm{H}_{2} \mathrm{~S}$ leading to vasorelaxation in vascular smooth muscle [11] and enhancing cardiovascular function [108]. Apart from $\mathrm{K}_{\mathrm{ATP}}$ channel, voltage-dependent calcium channels are also important targets of $\mathrm{H}_{2} \mathrm{~S}$, albeit there appears to be tissue-specificity [109]. In isolated mouse pancreatic $\beta$-cells [110] and rat cardiomyocytes [111], $\mathrm{H}_{2} \mathrm{~S}$ inhibited L-type VDCC currents; whereas in neurons, the activities of Cav3.2 T-type VDCCs and Cav1.2 L-type VDCCs were enhanced by endogenous and/or exogenous $\mathrm{H}_{2} \mathrm{~S}[112,113]$.

Solubility of $\mathrm{H}_{2} \mathrm{~S}$ in water is about $117 \mathrm{mmoles} / \mathrm{L}$ and when dissolved acts as a weak acid with the equilibrium: $\mathrm{H}_{2} \mathrm{~S} \leftrightarrow \mathrm{HS}^{-}+\mathrm{H}^{+} \leftrightarrow \mathrm{S}^{2-}+\mathrm{H}^{+}$. Only the first reaction is physiology relevant as the $\mathrm{pK}_{\mathrm{a} 1}$ is around 6.9 , which is approximately equivalent to the intracellular $\mathrm{pH}$ in many tissues and it is not far from the pH of mammalian blood (7.4) [114]. In the presence of oxygen and metal catalysts such as iron (III), $\mathrm{H}_{2} \mathrm{~S}$ is spontaneously oxidized, thus significantly reducing its concentration in a matter of hours [115]. Mitochondrial oxidation via three consecutive reactions is how much of the $\mathrm{H}_{2} \mathrm{~S}$ is metabolized [116]. In fact, $\mathrm{H}_{2} \mathrm{~S}$ is the only gasotransmitter that is enzymatically metabolized and the only inorganic compound that can be used by mammalian mitochondria to generate ATP [117, 118]. This oxidation requires one mole of oxygen for every mole of $\mathrm{H}_{2} \mathrm{~S}$ oxidized along the electron transport chain.

\section{Interaction between $\mathrm{NO}$ and $\mathrm{H}_{2} \mathrm{~S}$}

$\mathrm{NO}$ and $\mathrm{H}_{2} \mathrm{~S}$ share many similar actions, including modulation of leukocyte adherence to the vascular endothelium, both are "gasotransmitters", and both bind avidly to hemoglobin [10]. The interaction of hemoglobin with NO leads to the formation nitrosyl hemoglobin and with $\mathrm{H}_{2} \mathrm{~S}$ to the formation of green sulfhemoglobin [119]. Hemoglobin may also act as the common sink for $\mathrm{CO}$, forming scarlet carboxyhemoglobin [120]. The competition for the common hemoglobin sink can potentiate the biological activity of the other. NO can act as a 
reactive oxygen species (ROS) thus altering the reduced/oxidized glutathione balance; it can also inhibit enzymes and ion channels through S-nitrosylation [10]. It has also been suggested that $\mathrm{H}_{2} \mathrm{~S}$ may also be involved in the reduction of thiols [10, 121]. Recently, it was shown that the activity of myeloperoxidase (MPO), a haem protein that has been associated with many inflammatory events and cardiovascular diseases [122], was inhibited by $\mathrm{H}_{2} \mathrm{~S}$ reduction of its thiols [123]. There is considerable body of evidence strongly suggesting that $\mathrm{NO}$ and $\mathrm{H}_{2} \mathrm{~S}$ interact with each other, affecting each other's bioavailability and reactivity [124-126]. Most of the research on $\mathrm{NO}$ and $\mathrm{H}_{2} \mathrm{~S}$ cross-talk has been conducted in the cardiovascular system and the nature of this cross-talk in cancer is still unclear. Below I have presented an overview of this cross-talk in the cardiovascular system, however, I believe that these principles and mechanisms could essentially be applied to most cancers if not all.

In a cell-free system, it has been shown that NO inhibits CBS activity by binding to the heme group of the enzyme [127]. In a similar manner, that is the formation of a five coordinate ferrous nitrosyl complex impairing the binding of CBS to cysteine of homocysteine [126], NaSH has also been shown to directly inhibit a recombinant form of bovine eNOS most likely by an interaction between co-factors such as NADPH or tetrahydrobiopterin $[128,129]$. On the other hand, it has also been shown that $\mathrm{NO}$ can increase $\mathrm{H}_{2} \mathrm{~S}$ biosynthesis through increases in expression of CBS and CSE enzymes in vascular smooth cells [11, 130]. While $\mathrm{H}_{2} \mathrm{~S}$ has been shown to increase NO levels by increasing IL-1 $\beta$-induced iNOS expression again in vascular smooth cells [131] through NF- $\mathrm{kB}$ activation by a mechanism involving the ERK1/2 signaling cascade. In bovine arterial endothelial cells, $\mathrm{H}_{2} \mathrm{~S}$ has been shown to increase eNOS activation either indirectly by inducing its phosphorylation through an Akt-dependent mechanism [132] or directly by inducing $\mathrm{Ca}^{2+}$ release from the intracellular storage in the endoplasmic reticulum [133], thus providing yet another mechanism for its vasodilatory effects. These observations have been confirmed in human umbilical vein endothelial cells [134], where it was also found that L-cysteine supplementation stimulated NO production, while inhibition of CSE blocked it. Also, CSE knockdown inhibited, but CSE overexpression increased, NO production as well as endothelial cell proliferation. In these studies, LY294002 (Akt/PI3-K inhibitor) or SB203580 (p38 MAPK inhibitor) abolished the effects of $\mathrm{H}_{2} \mathrm{~S}$ on eNOS phosphorylation, NO production, and cell proliferation. In endothelial cells, $\mathrm{H}_{2} \mathrm{~S}$ increases cGMP in a NOdependent manner while inhibition of eNOS reduces both $\mathrm{H}_{2} \mathrm{~S}$-mediated angiogenesis and vasorelaxation [135].

$\mathrm{NO}$ and $\mathrm{H}_{2} \mathrm{~S}$ affect each other's synthesis as outlined above, however, they can also act directly to form novel molecular entities, which in turn exert further biological effects. For example, incubation of $\mathrm{NaSH}$ (releases $\mathrm{H}_{2} \mathrm{~S}$ ) with a range of $\mathrm{NO}$ donors and $\mathrm{NO}$ gas in vitro lead to the formation of a nitrosothiol molecule. The formation of this nitrosothiol was also shown in vivo using liver homogenates from LPS treated rats. The authors suggest that this nitrosothiol may regulate the physiological effects of both $\mathrm{NO}$ and $\mathrm{H}_{2} \mathrm{~S}$ [136]. The interaction between SNP (sodium nitroprusside, releases NO) or 2-(N,N-diethylamino)diazenolate-2-oxide (releases $\mathrm{NO}$ ) and $\mathrm{NaSH}$ produced an active intermediate species identified as HNO (nitroxyl, Angeli's salt), which induced an increase in the strength of myocardial contractility in rat hearts, which was opposite to the effects of either agent alone [137]. $\mathrm{H}_{2} \mathrm{~S}$ also reacts with S-nitrosothiols to form thionitrous acid (HSNO), the smallest S- 
nitrosothiol [138]. At the cellular level, HSNO can be metabolized to afford species such as $\mathrm{NO}^{+}, \mathrm{NO}$, and $\mathrm{NO}^{-}$, all of which have distinct physiological consequences of their own. Thus HSNO can act a signaling molecule that may play a key role in cellular redox regulation [138]. Emerging data shows that the interaction between $\mathrm{H}_{2} \mathrm{~S}$ and $\mathrm{NO}$ can also generate polysulfides $\left(\mathrm{H}_{2} \mathrm{~S}_{\mathrm{n}} ; \mathrm{H}_{2} \mathrm{~S}_{2}\right.$ and $\left.\mathrm{H}_{2} \mathrm{~S}_{3}\right)$ [139]. In this study it was shown that $\mathrm{H}_{2} \mathrm{~S}_{\mathrm{n}}$ generation was a fast reaction, and it activated transient receptor potential ankyrin 1 (TRPA1) channels in astrocytes and dorsal root ganglion (DRG) neurons, which can modify synaptic activity $[140,141] . \mathrm{H}_{2} \mathrm{~S}_{\mathrm{n}}$ has various other physiological effects. It facilitates the translocation of nuclear factor-like 2 (Nrf2) to the nucleus through modification of its binding partner, kelch-like ECH-associated protein 1 (Keap1), to up-regulate the transcription of antioxidant genes [142]. It also regulates the activity of a tumor suppressor, phosphatase and tensin homolog (PTEN) [143], activates protein kinase G1a (PKG1a) to relax vascular smooth muscle [144], and suppresses the activity of glyceraldehyde 3phosphate dehydrogenase (GAPDH) [145].

Recently, it was reported that incubation of RSNOs with excess $\mathrm{Na}_{2} \mathrm{~S}$ resulted in the formation of $\mathrm{SSNO}^{-}$(perthionitrite or nitrosopersulfide), which decomposed to NO and polysulfides at physiological $\mathrm{pH}[146,147]$. Since RSNOs can be formed from the interaction of $\mathrm{H}_{2} \mathrm{~S}$ and S-nitrosothiols [148], this strongly suggests that $\mathrm{H}_{2} \mathrm{~S}$ could regulate not only NO production from one of its own metabolites (RSNOs), but it could also affect and sustain RSNOs' reactivity and signaling. The main features of $\mathrm{NO}-\mathrm{H}_{2} \mathrm{~S}$ cross-talk are shown in Figure 2.

\section{The yin - yang of $\mathrm{NO}$ and $\mathrm{H}_{2} \mathrm{~S}$ in carcinogenesis}

NO has a dichotomous role in cancer biology, with some reports suggesting that NO possesses anti-tumor and antiinflammatory properties, while others implicate NO in tumor promotion and inflammation. For example, the production of endogenous NO is associated with apoptosis in cancer cells [149] characterized by upregulation of tumor suppressor p53, changes in expression of pro- and anti-apoptotic Bcl-2 family members, activation of caspases, chromatin condensation, and DNA fragmentation [150]. On the other hand, a large body of experimental and clinical data suggests a promoting role of NO in tumor progression and metastasis. Expression of iNOS has been reported in malignancies of the breast [77, 151, 152], prostate [153], lung [154], brain [155] and colon [156, 157]. It appears that, low concentrations of $\mathrm{NO}$ of less than $100 \mathrm{nM}$ prevents certain cell types from apoptosis, and thereby favor tumorigenesis and progression [158, 159]. A sustained low efflux of NO derived from eNOS stimulates the proliferation of the endothelail cells [160]. Whereas high concentrations of NO, more than $500 \mathrm{nM}$, may be pro-apoptotic, producing cytotoxicity and antitumor activity $[161,162]$. High NO levels that produced cytotoxic effects on tumor cells are derived from macrophages, neutrophils, endothelial cells, hepatocytes, cardiac myocytes and chondrocytes [163-166]. Thus NO displays a dual nature with respect to carcinogenesis, which may be attributed to low and high fluxes of NO [15$18,53,167,168]$.

The major sources of human exposure to NO are nitrovasodilators, which include nitroglycerine (glycerol trinitrate), amyl nitrite, isosorbide mono- and dinitrate, erythrityl 
tetranitrate and sodium nitroprusside [25]. These medications are taken sublingually, orally or subcutaneously for the treatment of angina pectoris and other coronary artery diseases. Nitroglycerine has been used effectively for over 100 years, and the other organic medicinal nitrates have been available since the 1930s. In theory, these medications can inhibit or promote the development of cancer. For example, glyceryl trinitrate induced apoptosis through activation of caspases in three different colon cancer cell lines [169] and inhibited tumor genesis in murine skin [170]. Further, isosorbide mononitrate and isosorbide dinitrate were shown to inhibit angiogenesis, tumor growth and metastasis in mice [171]. In contrast, feeding glyceryl trinitrate to F344 rats induced hepatocellular carcinomas that were characterized by K-ras point mutations [172]. Consistent with this finding is data showing elevated blood levels of nitrates and nitrites in patients with hepatocellular carcinoma [173].

Given the clinical importance and extensive use of NO-releasing vasodilators, the association between the commonly used NO-releasing nitrates and colorectal cancer risk was undertaken by using the data from the Framingham Heart and Offspring studies [174]. The Framingham Heart study is a long-term, multigenerational study, designed to identify genetic and environmental factors influencing the development of cardiovascular and other diseases [175]. Examination and testing of 5,209 residents of Framingham, Massachusetts, was initiated in 1948 and with approximately 200 members of the original cohort currently alive and under follow-up. An offspring cohort and a third generation cohort were subsequently added, followed more recently by two minority cohorts (Omni Group 1 and Omni Group 2) [176]. Using these data, it was concluded that nitrovasodilators do not increase the risk of colorectal cancer [174], reviewed in [25].

Statins are cholesterol-lowering drugs that are widely used in both men and women. As a class, they competitively and reversibly inhibit the enzyme 3-hydroxy-3-methylglutaryl-CoA (HMG-CoA) reductase, which is the rate-limiting enzyme for cholesterol biosynthesis in the liver; this leads to decreases in serum low-density lipoprotein cholesterol (LDL-C), triglyceride, and cholesterol levels [177]. It has been proposed that statins exert both LDL$\mathrm{C}-$ dependent and LDL-C-independent or pleiotropic effects [178, 179]. One of the pleiotropic effects of statins is upregulation of eNOS resulting in higher production endothelial NO, which is important for vasodilation, platelet aggregation, vascular smooth muscle proliferation, and endothelial-leukocyte interactions $[179,180]$. Statins upregulate eNOS activity through multiple mechanisms. One pathway involves Rho/ROCK signaling. In vitro studies show that Rho inhibition increases eNOS expression [181]. Statins also increase eNOS activity by post-translational activation of the phosphatidylinositol 3-kinase/ protein kinase Akt pathway as eNOS is phosphorylated by Akt [39]. Other pleiotropic effects of statins, which increase eNOS activity, include effects on caveolin 1; transcription factor kruppel-like factor-2; and mobilization of endothelial progenitor cells [179].

Emerging research suggests that statins may prevent various types of cancers, including colon [182-184] and breast [185-187] as well as ovarian, pancreatic, lung, and lymphomas, reviewed in [188]. Statins inhibit cancer cell proliferation by arresting the cell cycle at the $\mathrm{G}_{1}$-S phase and inducing apoptosis $[189,190]$. Fluvastatin inhibits epidermal growth factorinduced invasion of pancreatic cancer cells by inhibiting the translocation of RhoA from the cytosol to the membrane [191]. Furthermore, statins have been shown to inhibit in vivo 
tumor growth at clinically relevant doses and to diminish metastasis in animal models [192, 193]. Of interest, simvastatin and fluvastatin have been shown to enhance NO levels through increases in iNOS mRNA and protein expression. Statin induced NO and tumor cell cytotoxicity was inhibited by $1400 \mathrm{~W}$ [N-(3-aminomethyl)benzylacetamidine], a relatively specific iNOS inhibitor [194].

It is important to note that these agents have been used for more than 30 years. They induce iNOS and/or eNOS, yet there is no data to suggest that people who have been using these drugs essentially for long period of times, are at a greater risk of developing any kind of cancer.

Much like $\mathrm{NO}, \mathrm{H}_{2} \mathrm{~S}$ also has a dichotomous role in inflammation, immunity, and cancer biology, with some studies suggesting anti-inflammatory, anti-cancer effects, whereas others suggest a contribution to immune-mediated tissue injury and tumor promotion. For example, CSE and myeloperoxidase (MPO) activity were increased in the carrageenan-induced rat hindpaw model of inflammation. Pretreatment with DL-propargylglycine which is a CSE inhibitor reduced this edema [195]. Endotoxin administration to mice increased CSE gene expression in liver and kidney and increased $\mathrm{H}_{2} \mathrm{~S}$ levels in the plasma, liver, and kidney with histological evidence of lung, liver, and kidney tissue inflammatory damage [196]. NaSH administration resulted in histological signs of lung inflammation, increased lung and liver MPO activity, and increased plasma TNF-a levels [196]. Elevated $\mathrm{H}_{2} \mathrm{~S}$ levels have also been observed in the plasma of septic shock patients [196]. Interestingly, when NO-releasing flurbiprofen was administered to LPS treated rats, there was a dose-dependent inhibition of liver $\mathrm{H}_{2} \mathrm{~S}$ synthesis and CSE mRNA levels [197, 198]. Taken together, these observations suggest a proinflammatory role for $\mathrm{H}_{2} \mathrm{~S}$. Proinflammatory actions of $\mathrm{H}_{2} \mathrm{~S}$ have also been reported in an animal model of pancreatitis [22, 23].

Anti-inflammatory effects of $\mathrm{H}_{2} \mathrm{~S}$ have also been reported. For example, administration of carrageenan into a rat air pouch resulted in leukocyte and neutrophil infiltration.

Pretreatment with various $\mathrm{H}_{2} \mathrm{~S}$ donors, ( $\mathrm{NaSH}, \mathrm{N}$-acetylcysteine, Lawesson's reagent) reduced the number of leukocytes in a dose-dependent manner [13]. This reduction was comparable to that seen by using the NSAID, diclofenac; the NOS inhibitor, L-NAME $\left(N_{\omega^{-}}\right.$ Nitro-L-arginine methyl ester); or dexamethasone. Pretreatment with $\beta$-cyanoalanine, a CSE inhibitor reversed the inhibitory effects of $\mathrm{N}$-acetylcysteine. Pretreatment with diclofenac, $\mathrm{NaSH}$, or $\mathrm{Na}_{2} \mathrm{~S}$ similarly reduced carrageenan-induced rat paw edema while $\beta$-cyanoalanine showed a significant increase in paw swelling in response to carageenan [13].

Through peroxynitrite scavenging, $\mathrm{H}_{2} \mathrm{~S}$ may inhibit tissue oxidative damage $[199,200] \cdot \mathrm{H}_{2} \mathrm{~S}$ has been shown to induce apoptosis in neutrophis [201], which could contribute to resolution of inflammation [202]. In LPS-stimulated microglia and astrocytes, $\mathrm{H}_{2} \mathrm{~S}$ donors inhibited TNF- -inflammatory effect, due to inhibition of iNOS and p38 MAPK signaling [203]. In the neuroblastoma cell line $\mathrm{SH}-\mathrm{SY} 5 \mathrm{Y}, \mathrm{H}_{2} \mathrm{~S}$ inhibited rotenone-induced cell apoptosis via regulation of p38- and JNK-MAPK pathway [204]. Thus it appears that just like NO, physiological concentrations of $\mathrm{H}_{2} \mathrm{~S}$ produce anti-inflammatory effects, where as higher concentrations may be pro-inflammatory $[19,20]$. 


\section{Modulation of NO levels as a strategy to treat cancer}

Different approaches have been used in utilizing NO as an anticancer target. These have included using NO as a radiotherapy and chemotherapy sensitizer, NO-releasing drugs, and NOS inhibitors [205]. Since tumors in general do not have well developed vasculature, administered drugs may not reach their intended target. NO donors can enhance tumor blood flow and oxygen supply, thereby resensitizing the tumor to chemotherapeutic agents and/or radiation therapy. While NO-releasing agents and NOS inhibitors have opposing effects, they both can serve as anticancer agents, as it has often been said, "the devil is in the details". In the following sections, I have visited each of these areas; some briefly with appropriate references to in-depth reviews and some in more detail.

\subsection{Using NO as a radiotherapy and chemotherapy sensitizer}

Radiation is used in some instances to decrease tumor size before surgery. Unfortunately, many tumors are radio resistant mainly due to tumor hypoxia, with the degree of hypoxia correlating well with the response to radiation [206-208]. After $\mathrm{O}_{2}, \mathrm{NO}$ is the second most potent chemical radio sensitizer [209, 210]. In a xenograft model of colorectal cancer, NO and ionizing radiation synergistically promoted apoptosis and growth inhibition by activating p53, further iNOS gene transfer enhanced tumor radio responsiveness [211].

Resistance of cancer cells to drug induced apoptosis is a hallmark mechanism of resistance. Tumor cells develop various mechanisms to escape the cytotoxic and antiproliferative effects of chemotherapeutic drugs. Understanding the underlying mechanisms of resistance may lead to the development of novel therapeutics. While chemotherapy remains one of the most common treatment options for various cancers, whether used alone as a single agent or in combination, its clinical effectiveness is limited due to the resistant phenotype of cancers in general. Both innate and adaptive chemoresistance have been characterized. The innate or intrinsic resistance is the resistance before treatment due to the presence of a subset of resistant cancer stem cells (CSCs) and of various resistant factors in the tumor cells that make them resistant to chemotherapy. The adaptive or acquired resistance develops following treatment as a result of various mechanisms such as mutations, overexpression of the therapeutic targets, and alternative compensatory signaling pathways [212-214]. Several mechanisms have been reported to overcome chemotherapy resistance [213], these have been thoroughly reviewed recently [212]. Another problem encountered in chemotherapy is the development multidrug resistance (MDR). This is a phenomenon by which tumor cells that have been exposed to a cytotoxic agent develop cross-resistance to a range of structurally and functionally unrelated compounds. MDR is one of the major obstacles to the successful pharmacologic treatment of tumors [215-217].

When MCF-7 human breast cancer cells were exposed to an aqueous solution of NO delivered as a bolus $30 \mathrm{~min}$ prior to doxorubicin, the cytotoxic effect of the combination was greater than that of doxorubicin alone. The NO donor diethylamine nitric oxide, but not inactivated donor, also increased doxorubicin cytotoxicity. Of note, the treatment sequence was important since the simultaneous application of $\mathrm{NO}$ with doxorubicin was not all that effective, and the exposure of the cells to doxorubicin prior to the NO obliterated the augmentation [218]. Treatment of the doxorubicin-resistant epithelial colon cancer cell line 
(HT29-dx) with a variety of diverse NO donors (SNAP, GSNO, and SNP) or the induction of iNOS by a cytokine mixture (IFN- $\gamma$, TNF- $a$, and IL-1 $\beta$ ) or the statin, atorvastatin resulted in the reversal of resistance [215]. This effect was mediated, in part; by tyrosine nitration of MDR associated protein and the inhibition of drug efflux. NO donors also increased drug accumulation in two other doxorubicin-resistant cell populations that is of lung epithelial cells A549 and the human myelogenous leukemic cells K562 [215]. Treatment of cisplatinresistant prostate cancer cells by the NO donor DETANONOate sensitized the resistant tumor cells to apoptosis by CDDP (cisplatin-diamine-dichloro platinum) and the combination was synergistic [219]. Treatment with DETANONOate inhibited the constitutively activated prosurvival/antiapoptotic signaling pathway mediated by NF- $\kappa \mathrm{B}$, which was shown to be as a result of S-nitrosylation of both p50 and p65 subunits [212, 220, 221]. meta-NO-releasing aspirin (NCX-4016) [222] was evaluated against cisplatin-sensitive and cisplatin-resistant (CR) human ovarian cancer cells (HOCCs) [223]. NCX-4016 significantly reduced the surviving fractions of cisplatin-sensitive and CR HOCCs. Treatment of cells with NCX-4016 followed by cisplatin showed a significantly greater extent of toxicity when compared with treatment of cells with either agent alone. NCX-4016 inhibited EGFR and STAT-3 signaling and, hence, increased the levels of p53 and Bax and decreased the levels of Bcl-xL, survivin, and cyclin D1, resulting in the inhibition of proliferation and the induction of apoptosis by cisplatin. Using colon cancer xenografts, simultaneous treatment with oxaliplatin and para-NO-aspirin (NCX-4040) or oxaliplatin followed by NCX-4040 showed comparable additive effects. However, treatment with NCX-4040 followed by oxaliplatin showed synergistic interactions possibly by sensitizing the cancer cells to the cytotoxic effects of oxaliplatin [224]. RRx-001 (see the following section) is a novel aerospace-derived compound under active investigation as a chemo-, immuno- and radiosensitizer in Phase II clinical trials [225]. Results from a Phase-I clinical trial of RRx-001 in heavily pretreated patients with advanced/refractory solid tumors showed evidence of anticancer efficacy, with 15 of 25 patients enrolled in the study exhibiting partial response or stable disease [226]. Furthermore, after progression on RRx-001 treatment, 4 patients were re-challenged with drugs to which they had previously acquired resistance, and all 4 exhibited re-sensitization. In a recent case report [227], a patient with platinumresistant small-cell lung cancer (SCLC) was successfully rechallenged with cisplatin/ etoposide after being treated with RRx-001. The authors conclude that "the prolonged partial response of this platinum-resistant SCLC to reintroduced carboplatin/etoposide after RRx-001 belies and contradicts the prevailing orthodoxy in oncology that rechallenge with chemotherapy after the emergence of resistance is an exercise in futility and risk, which potentially exposes patients to toxicity without benefit".

\section{2. "Designer" NO-releasing compounds as chemotherapeutic agents}

There are many synthetic "designer" NO-releasing compounds that are at various stages of development; some are preclinical, some are in different phases of clinical trials and some have been abandoned for various reasons $[18,25]$. Below, I have briefly discussed some of these promising NO-releasing compounds that have utility against various cancers and have provided some recent in-depth reviews of the subject matter. 
5.2.1. Nitric oxide-releasing NSAIDs (NO-NSAIDs)-NO-NSAIDs were developed to reduce the potential side effects associated with traditional NSAIDs [228, 229]. The rationale for their development was largely based on the observations that in the gastrointestinal (GI) system NO can enhance the local mucosal defense mechanisms thus increasing blood flow, mucus and bicarbonate secretions [7], reviewed in [25, 230]. NONSAIDs are traditional NSAIDs linked to an NO-releasing moiety via an aliphatic or an aromatic spacer (Fig 3A). All NO-NSAIDs tested were more potent in inhibiting the growth of various human cancer cell lines compared to their traditional counterparts [231]. Aromatic spacers generated more potent NSAID derivatives than aliphatic ones [222, 232], and positional isomerism greatly influenced all cell kinetic parameters that influence cellular mass. It should be noted that although structure-activity studies with NO-aspirin had indicated that $\mathrm{NO}$ was pivotal for its anticancer effects [233] it also became apparent that in cases where the spacer was aromatic, the biological actions may have been due to formation of a putative quinone methide (QM) intermediate [234-236]. NO-NSAIDs have shown efficacy in various animal models of cancer, including a rat model of colonic adenocarcinoma [237], Min (APC Min/+ $)$ mouse [238], F344 rats treated with the carcinogen, azoxymethane [239], pancreatic cancer [240], urinary bladder cancer [241], and estrogen receptor negative breast cancer [242]. Molecular targets of NO-NSAIDs in cancer have been thoroughly reviewed elsewhere $[25,230]$.

\subsubsection{Diazeniumdiolate based NO-releasing compounds and HNO-NSAIDs-}

Decomposition of diazeniumdiolates or NONOates can lead to the formation of nitroxyl (HNO) and/or NO [243, 244] (Fig 3B). HNO has beneficial effects in overcoming heart failure [245], preconditioning against myocardial infarction [246], and treating alcohol abuse [247]. The first anticancer activity of $\mathrm{HNO}$ which was generated using Angeli's salt $\left(\mathrm{Na}_{2} \mathrm{~N}_{2} \mathrm{O}_{3}\right)$ was reported in 2008 [248] where it was shown that it suppressed proliferation of human breast cancer cell lines under both hypoxic and normoxic conditions and in xenografts.

IPA/NO-aspirin and DEA/NO-aspirin (Fig 3C) are two relatively new NONO-NSAIDs [249] with enhanced GI safety profiles, strong anti-inflammatory properties, and significant cytotoxcity compared to either aspirin or the parent diazeniumdiolate toward nonsmall cell lung carcinoma cells (A549) [250]. Both IPA/NO-aspirin and DEA/NO-aspirin were equally effective against hormone sensitive and insensitive breast cancer cell lines with no appreciable cytoxicity towards a related nontumorigenic cell line.

5.2.3. JS-K and PABA/NO-JS-K (Fig 3D) and PABA/NO (Fig 3E) are members of the diazeniumdiolate class of NO-releasing prodrugs that were designed to be activated by glutathione- $S$-transferase (GST) [251]. The rationale for this was based on the observation that GST- $\pi$, one of the phase II detoxification metabolizing enzymes is frequently overexpressed in most cancers. JS-K [252, 253] and PABA/NO [254, 255] have shown promise as anti-cancer agents. In brief, JS-K has shown efficacy against leukemia, renal, prostate, and brain cancer cells, both ER-positive and ER-negative breast cancer cell lines without affecting normal mammary epithelial cells, primary glioblastoma cells, and lung adenocarcinoma cells [252, 256-259]. Mechanistically, dearylation of the diazeniumdiolate 
by GSH causes release of two equivalents of NO [260] and rapid depletion of GSH, resulting in alterations in the redox potential of the cellular environment, and activation of the MAPK stress signaling pathways, and induction of apoptosis. In Acute Lymphoblastic Leukemia (ALL) cell lines, JS-K inhibited growth, reduced proliferation, caused cell cycle arrest, increased apoptosis, and reduced the transcriptional activity of $\beta$-catenin [261, 262].

\subsubsection{RRx-001 an endogenously NO generating compound: The aerospace connection-RRx-001 (Fig 3F) also known as ABDNAZ (1-bromoacetyl-3,3-} dinitroazetidine) is a novel aerospace-derived compound that differs from other NOdonating compounds in that the molecule induces local, endogenous and biphasic production or release of NO, rather than fragmenting to release NO systemically, reviewed in [18]. This compound contains a unique high energetic organic nitro functional group, a gem dinitroazetidine that has not been used to date for medical and pharmaceutical applications. In an aerospace setting, compounds containing this energetic functionality, such as 1,3,3 trinitroazetidine, are designed to fragment explosively to propel rockets [263]. Modification of this structure by removing one of the nitro groups and substituting it with a bromoacetate group resulted in RRx-001, a nonexplosive that may be used to treat cancer [25, 264]. On infusion, the compound rapidly, irreversibly and selectively binds to hemoglobin [265], and with glutathione [266, 267] causing increases in oxidative stress [268]. While the RRx-001 glutathione adduct is rapidly excreted, RRx-001-bound hemoglobin remains in circulation for the duration of the lifetime of the red blood cell [269]. RRx-001 effectively inhibited the growth of eleven human cancer cell lines of varying tissue origins [270] by inducing intracellular ROS and RNS in a dose- and time-dependent manner. In some studies, DNA damage ( $\gamma \mathrm{H} 2 \mathrm{AX}$ expression) was observed the implication of which is that RRx-001 may be used as a chemotherapeutic agent but has no potential utility as a chemopreventive one.

\subsection{Inhibition of iNOS/eNOS as strategies to treat cancer}

All NOS isoforms metabolize L-arginine to L-citrulline and NO via two consecutive NADPH-dependent monooxygenation reactions. Two identical monomers constitute the active NOS, each having a C-terminal reductase and an N-terminal oxygenase domain. In mammals, all three isoforms contain highly conserved catalytic cores, which historically was an obstacle when attempting to find a specific inhibitor of a particular isoform [271]. The Xray crystal structures of iNOS [272,273] and eNOS [274] became available in the late 1990s and that of nNOS in 2002 [275]. These allowed for computer-based drug design of each isoform [276]. Potential therapeutic and challenges in developing NOS inhibitors have been reviewed in $[277,278]$.

In many clinical cancer studies, high iNOS expression has correlated relatively well with poor patient survival. These include colon, breast, gastric, hepatocellular carcinoma, melanoma, ovarian, leukemia, gastric, prostate, esophageal, and cervical [279, 280]. It has thus been suggested that iNOS expression may be used as a biomarker of poor patient prognosis and perhaps survival [281, 282]. By contrast, favorable prognosis has been associated with high iNOS expression in ovarian (10-year prognosis) [283] and non-small cell lung cancers [284]. 
Treatment of triple-negative breast cancer (TNBC) cell lines, which express high levels of iNOS with $1400 \mathrm{~W}$, which is a highly selective iNOS specific inhibitor, L-NAME which is a relatively selective eNOS inhibitor, and L-NMMA, which is pan-NOS inhibitor reduced cell proliferation, migration, and mammosphere formation [57]. In the same study, using a xenograft model of TNBC, treatment of mice with L-NAME, and L-NMMA significantly reduced tumor growth. Clinically, L-NMMA causes an acute elevation in blood pressure through inhibition of eNOS, which is what was seen in this study. To counteract this, the anti-hypertensive agent amlodipine was also incorporated. Administration of AG, another iNOS specific inhibitor instead of $1400 \mathrm{~W}$ which has shown toxicity at high doses [285] to athymic nude mice bearing TNBC xenografts, abated tumor growth and metastatic burden [55]. Further, growth of glioma [286] or melanoma [287] cells in xenografts was significantly reduced when iNOS was silenced in these cells before they were implanted. The overarching data from all of these studies is the observation that the enhanced growth of the iNOS-overexpressing tumors appears to be due to enhanced angiogenesis.

\section{Modulation of $\mathrm{H}_{2} \mathrm{~S}$ levels as a strategy to treat cancer}

The therapeutic potential of $\mathrm{H}_{2} \mathrm{~S}$-donating compounds have been described in the cardiovascular system [288, 289], urology [290], neuroinflammation [291], and ophthalmology [292]. These general areas have been thoroughly reviewed elsewhere [34, $109,293]$. Here I have focused on modulation of $\mathrm{H}_{2} \mathrm{~S}$ levels and the role of $\mathrm{H}_{2} \mathrm{~S}$-donating compounds that are in different stages of development as agents that may have utility against cancer, although where appropriate, I have also summarized some novel compounds that have other indications.

It should be noted that in the literature the terms $\mathrm{H}_{2} \mathrm{~S}$-donating and $\mathrm{H}_{2} \mathrm{~S}$-releasing are used almost synonymously, but actually they represent two very different phenomenons. $\mathrm{H}_{2} \mathrm{~S}$ releasing compounds can be classified as sulfide salts such as $\mathrm{NaSH}, \mathrm{Na}_{2} \mathrm{~S}$ and $\mathrm{CaS}$, which form $\mathrm{HS}^{-}$and $\mathrm{H}_{2} \mathrm{~S}$ immediately upon solvation in physiological buffers. These compounds are extensively used in studying the biological actions of $\mathrm{H}_{2} \mathrm{~S}$, however, they are of limited therapeutic value since their effective residence time in tissues is relatively short [18]. $\mathrm{H}_{2} \mathrm{~S}$ donating compounds are either naturally occurring compounds (mainly in foods) or synthetic hybrids, which can donate/deliver their $\mathrm{H}_{2} \mathrm{~S}$ "payload" either slowly or relatively rapidly depending on the inherent nature of the molecules.

\section{1. $\mathrm{H}_{2} \mathrm{~S}$ as a radio /chemo -sensitizer}

There are only a few reports addressing the potential use of $\mathrm{H}_{2} \mathrm{~S}$ as an adjuvant in radiotherapy or as a chemosensitizer. When HepG2 cells that were maintained under hypoxic conditions were treated with PPG and AOAA, which putatively are specific inhibitor of CSE and CBS respectively, radiation responses including cell killing, micronuclei MN formation, and caspase-3 activity were significantly enhanced [294]. Actually, AOAA is not very selective, as it also inhibits CSE [295]. However, treatment of these cells with low concentrations of $\mathrm{NaSH}(\leq 100 \mu \mathrm{M})$ had a protective effect against radiation damages but higher concentrations increased cytotoxicity. Thus, $\mathrm{H}_{2} \mathrm{~S}$ may confer intrinsic radioresistant properties to these cancer cells. The beneficial effects of $\mathrm{H}_{2} \mathrm{~S}$ as co- 
treatment to radiotherapy were evaluated in vivo using xenograft models of cervix and ER(-) breast cancers [296]. Using electron paramagnetic resonance (EPR) oximetry, it was shown that a single $\mathrm{NaSH}$ administration decreased oxygen consumption and increased tumor perfusion. Tumors irradiated 15 minutes after $\mathrm{NaSH}$ administration were more sensitive to irradiation compared with those that received irradiation alone. As eluded above, tumor hypoxia, arising from an imbalance between oxygen consumption and blood supply, is a major cause of resistance to radiotherapy. Thus this study underscores the importance of $\mathrm{H}_{2} \mathrm{~S}$ in radiosensitization that were due to improved tumor oxygenation.

Effects of $\mathrm{H}_{2} \mathrm{~S}$ in combination with conventional chemotherapeutic agents appear to be controversial. Cisplatin (CP) is a potent chemotherapeutic agent for the treatment of many solid- organ cancers. However, nephrotoxicity is a major side effect of its use, affecting 20$30 \%$ of patients. Several lines of evidence indicate that CBS plays an important role in regulating the redox balance and metabolism of the ovarian cancer cells promoting tumor growth and metastasis [99]. Of note, in vitro effects of CBS silencing was reversed by addition of $\mathrm{Na}_{2} \mathrm{~S}$ in three different ovarian cancer cell lines. Silencing $\mathrm{CBS}$ in a CP-resistant orthotopic model in vivo by nanoliposomal delivery of CBS siRNA inhibited tumor growth, reduced nodule formation and sensitized ovarian cancer cells to CP. Thus in this study, CBS promoted ovarian tumor growth and maintained drug resistant phenotype by controlling cellular redox behavior and mitochondrial bioenergetics. In another study, CP-treated rats presented with increases in plasma creatinine and BUN levels, urinary volume and sodium and potassium fractional excretions [297]. Treatment with PAG an inhibitor of CSE reduced all these alterations. Thus, the animals treated with PAG $+\mathrm{CP}$ presented less renal damage compared with those injected with $\mathrm{CP}$ alone. This protective effect appeared to be due to diminished inflammation.

In a recent study evaluating the effects of $\mathrm{H}_{2} \mathrm{~S}$ on CP-induced nephrotoxicity in rats [298], it was reported that administration of $\mathrm{NaSH}$ reversed $\mathrm{CP}$-induced changes and prevented the progression of $\mathrm{CP}$ nephrotoxicity, potentially through its cytoprotective/antioxidant properties. To the contrary, administration of GYY4137, a slow $\mathrm{H}_{2} \mathrm{~S}$-donating compound to mice, exacerbated CP-induced nephrotoxicity [299]. Mice were pretreated with GYY4137 for $72 \mathrm{~h}$ prior to $\mathrm{CP}$ injection. $\mathrm{CP}$ treated mice developed renal dysfunction and kidney injury, with elevated BUN, histological damage and increases in TNF- $a$, IL-6, and IL- $1 \beta$, caspase-3, Bak, and Bax. All these markers were significantly increased by GYY4137 pretreatment. Thus this study suggested that GYY4137 exacerbated CP-induced nephrotoxicity in mice potentially through increases in oxidative stress and inflammation.

\subsection{Synthetic $\mathrm{H}_{2} \mathrm{~S}$-donating compounds as chemotherapeutic agents}

6.2.1. GYY4137 and its structural analogs-The first water-soluble slow $\mathrm{H}_{2} \mathrm{~S}$ donating molecule to be described was GYY4137 (morpholin-4-ium 4 methoxyphenyl(morpholino) phosphinodithioate [300] (Fig 4A, Table 1). GYY4137 inhibited growth of different human cancer cell lines including cervical carcinoma (HeLa), colorectal carcinoma (HCT-116), hepatocellular carcinoma (HepG2), osteosarcoma (U2OS), breast adenocarcinoma (MCF-7), acute promyelocytic leukemia cells (HL-60), and myelomonocytic leukemia (MV4-11) [301] but did not affect survival of non-cancer human 
diploid lung fibroblasts (IMR90 and WI-38). In xenograft models of leukemia, GYY4137 $(100-300 \mathrm{mg} / \mathrm{kg}$ ) decreased tumor growth [301] and in HepG2 xenografts it inhibited STAT3 activation and its target gene expression [302]. GYY4137 has been shown to increase glycolysis, leading to overproduction of lactate, inducing intracellular acidification and cancer cell death [303]. It should be noted that commercial preparations of GYY4137 are sold as a dichloromethane complex, and it has been reported that dichloromethane is metabolized to carbon monoxide (CO) $[304,305]$ an important gasotransmitter. Since CO is reported to have similar biological effects as $\mathrm{H}_{2} \mathrm{~S}$ [306-308], it is possible that some of the observed effects of GYY 4137 could also be due, at least in part, to a contribution by CO [289].

The concentrations of GYY4137 needed to see any biological/pharmacological effects are rather high. To improve $\mathrm{H}_{2} \mathrm{~S}$ generation, modifications to the phosphorodithioate core were made resulting in agents, which generate $\mathrm{H}_{2} \mathrm{~S}$ at different rates (AP67, AP72, AP105, AP106) [289]. Potential anti-cancer activity of these agents is yet to be reported.

6.2.2. $\mathrm{H}_{2} \mathrm{~S}$-donating NSAIDs- $\mathrm{H}_{2} \mathrm{~S}$-donating NSAIDs are a keen to the NO-releasing NSAIDs described above. ADT-OH, (5-(4-hydroxyphenyl)-3 H-1,2-dithiole-3-thione) the main metabolite of ADT (anethole dithiolethione (Fig 4B) has been used extensively as a $\mathrm{H}_{2} \mathrm{~S}$ donor with many therapeutic agents including a good number of NSAIDs, reviewed in [81, 309]. $\mathrm{H}_{2} \mathrm{~S}$-donating NSAIDs, (HS-aspirin, HS-sulindac, HS-ibuprofen, HS-naproxen, Fig 4C) were shown to have utility as anti-cancer agents [310-315]. Human safety data on some $\mathrm{H}_{2} \mathrm{~S}$-donating NSAIDs are beginning to emerge although not yet published (pharmaceutical press releases), underscoring the great potential of these agents against many diseases including cancer. $\mathrm{H}_{2} \mathrm{~S}$-donating NSAIDs in general inhibit cell proliferation, enhance cell death by inducing apoptosis, and they block transitions through the cell cycle, predominantly that between $\mathrm{G}_{0} / \mathrm{G}_{1}[310,311]$. The net result being a significant inhibition of cell growth, which presumably, accounts for the ultimate inhibition of carcinogenesis that is observed in vivo. HS-aspirin, HS-sulindac, HS-naproxen, and HS-ibuprofen inhibited growth of eleven different cancer cell lines of six different histological subtypes [311].

Another $\mathrm{H}_{2} \mathrm{~S}$-donating moiety that has been employed with NSAIDs to produce HSNSAIDs hybrids is 4-hydroxy benzothiazamide (TBZ, Fig 4D). This moiety has been conjugated with naproxen (ATB-346, Fig 4E) and aspirin (NBS-1121, Fig 4H). In an animal model of synovitis, ATB-346 reduced edema and pain score suggesting possible use in treatment of patients with arthritis [316]. ATB-346 has also shown efficacy against azoxymethane induced colon cancer [313] and was also more effective at preventing intestinal polyp formation than naproxen in the $\mathrm{APC}^{\mathrm{Min}+}$ mice. In this model, ATB-346 but not naproxen, significantly decreased expression of intestinal cancer-associated signaling molecules, cMyc and $\beta$-catenin [315]. ATB-346 also reduced proliferation and increased apoptosis of human melanoma cells, an effect that was modulated by inhibition of NF- $\mathrm{\kappa B}$ activation and inhibition of Akt signaling pathway. Moreover, daily oral dosing of ATB-346 significantly reduced melanoma development in vivo [314]. ATB-346 (Table 1) is being developed for the treatment of osteoarthritis, and has completed Phase-I clinical trials in healthy volunteers and is now under Phase-II clinical evaluation. 
Recently, a series of $\mathrm{H}_{2} \mathrm{~S}$-donating NSAIDs have been reported that utilize not only ADT$\mathrm{OH}$, or TBZ, but also 1,2-dithiolane (Fig 4J) [317]. Some of these HS-NSAIDs are based on traditional NSAIDs that are nonselective COX inhibitors that have not been reported earlier, some are COX-2 selective, and some are based on acetaminophen. There is limited cell growth inhibition data available for these compounds and none have been evaluated in any animal models of cancer.

In a recent review [105], it was suggested that the $\mathrm{H}_{2} \mathrm{~S}$ released from $\mathrm{H}_{2} \mathrm{~S}$-donating NSAIDs was unlikely to contribute to the overall activity of these class of compounds and that in the studies reported no information was presented on the relative contribution of $\mathrm{H}_{2} \mathrm{~S}$ versus the parent (NSAID) molecule to the anticancer effects. A close examination of the published work shows that indeed such information was available [81,311,318]. Structure-activity and reconstitution studies of the individual components of HS-NSAIDs; the parent NSAID and the ADT-OH moiety on the growth properties of HT-29 human colon cancer cells showed that the combination of these two molecules did not reconstitute the potency of the intact HS-NSAIDs. Furthermore, when $\mathrm{H}_{2} \mathrm{~S}$ release from HS-aspirin was blocked when evaluating the effects of HS-aspirin on cell growth in MDA-MB-231 breast cancer line, the $\mathrm{IC}_{50}$ for cell growth inhibition was increased by about 60 -fold, clearly demonstrating a significant contribution by $\mathrm{H}_{2} \mathrm{~S}$ to cell growth inhibitory effects of HS-aspirin [310].

6.2.2.1. Molecular targets of $\mathbf{H}_{2} \mathbf{S}$-donating NSAIDs in cancer-Apart from effects on cell kinetics (proliferation, cell cycle arrest, apoptosis), which ultimately determine cellular mass, HS-NSAIDs also modulate a number of molecular targets that are important in cancer. These have been thoroughly reviewed elsewhere [18, 81, 309]. These include, NFкB [310, 319-322]; ROS [310]; thioredoxin/thioredoxin reductase-1 (Trx/TrxR) [310, 322]; wnt/ $\beta$-catenin signaling [323]; and xenobiotic metabolizing enzymes [312].

6.2.3. NOSH-NSAIDs: Dual NO- $\mathrm{H}_{2} \mathrm{~S}-$ donating hybrids-Based on the chemistry of $\mathrm{NO}$ and $\mathrm{H}_{2} \mathrm{~S}$, and the structural components of NO-NSAIDs and HS-NSAIDs, my lab postulated that an NSAID possessing moieties that could donate both of these gasotransmeters might be more potent and effective than either one alone [324]. This led to the synthesis and characterization of a new class of anti-inflammatory and anti-cancer compounds, that I have coined NOSH-NSAIDs, of which six have been reported thus far $[262,318,324]$. The structural components of three of these compounds are shown in Fig 4G-I. In terms of GI safety, NBS-1120 [325], AVT-219 [326], and NOSH-sulindac (AVT-18A) [327] were essentially devoid of any GI toxicity. All three compounds exhibited comparable pharmacological properties to their respective parent compound but unlike their native counterparts were GI safe. The antinociceptive activity of NBS-1120 was compared with aspirin in different models of inflammatory pain [328]. Mechanistically, NBS-1120, but not aspirin, was able to reduce the production/release of IL- $1 \beta$ during carrageenan-induced paw inflammation. Furthermore, NBS-1120, but not aspirin, reduced prostaglandin E2induced hyperalgesia, which was prevented by treatment with a ATP-sensitive $\mathrm{K}_{\text {ATP }}$ blocker (glibenclamide). The enhanced effects of NBS-1120 appear to be due to its ability to reduce the production of pronociceptive cytokines such as IL-1 $\beta$ and directly block hyperalgesia 
caused by a directly acting hyperalgesic mediator in a mechanism dependent on modulation of $\mathrm{K}_{\mathrm{ATP}}$ channels.

The cell growth inhibitory properties of NBS-1120, NBS-1121, AVT-219, and AVT-18A were evaluated in eleven different human cancer cell lines of six different histological subtypes [325-327]. All four NOSH compounds were extremely effective in inhibiting the growth of these cell lines, however, NBS-1120 was the most potent, with $\mathrm{IC}_{50} \mathrm{~s}$ for cell growth inhibition ranging from $48-280 \mathrm{nM}$ at $24 \mathrm{~h}$ [324, 326, 327].

Treatment of athymic nude bearing a human colon cancer xenograft with NBS-1120 at a dose of $100 \mathrm{mg} / \mathrm{kg}$ caused an $85 \%$ reduction in tumor growth after 18 days of treatment [262]. Further, in a xenograft mouse model of colon cancer chemoprevention, aspirin at a dose of $50 \mathrm{mg} / \mathrm{kg}$ and NBS-1120 at different doses $(25-100 \mathrm{mg} / \mathrm{kg}$ ) inhibited tumor growth and tumor mass with NBS-1120 being $\sim 5$-fold more potent than aspirin [325]. Of note was the observation that the stomachs of the aspirin-treated mice exhibited erosions consistent with pre-ulcer development [329]. Thus as a chemo-preventive agent, NBS-1120 appears to be superior to aspirin both in terms of efficacy and safety. In another study comparing the chemotherapeutic efficacy of AVT-219 to that of naproxen in a xenograft mouse model of colon cancer, it was reported that all the mice treated with naproxen died within 2 weeks from what appeared to be sever GI bleeding and damage to the spleen and liver. However, the AVT-219 treated mice did not show any overt signs of toxicity and after 30 days of treatment the AVT-219-treated mice showed a considerable reduction in tumor growth compared with untreated mice which was as a result of increased apoptosis and reduced cell proliferation [326].

\subsection{Other $\mathrm{H}_{2} \mathrm{~S}$-donating agents of therapeutic interest}

Within the mitochondria $\mathrm{H}_{2} \mathrm{~S}$ appears to have antioxidant properties, modulating mitochondrial cell death pathways and cellular bioenergetics [121, 330, 331]. Mitochondria targeted $\mathrm{H}_{2} \mathrm{~S}$ donors have been developed by coupling DTT with a phosphonium salt. One of such donors, AP39 ([(10-oxo-10-(4-(3-thioxo-3H-1,2-dithiol-5yl) phenoxy)decyl) triphenyl phosphonium bromide], (Fig 5A, Table 1), has shown promising activities [332]. Compared to standard and non-mitochondria-targeted donors such as GYY4137 and ADT-OH, AP39 significantly inhibited the oxidative stress-induced toxicity. It also attenuated the loss of cellular bioenergetics during oxidative stress and protected against oxidative mitochondrial DNA damage. These results suggest that mitochondria targeting is important.

Since $\mathrm{H}_{2} \mathrm{~S}$ appears to reduce visceral pain [333-335], an $\mathrm{H}_{2} \mathrm{~S}$-releasing salt of trimebutine has been developed (GIC-1001, Fig 5B, Table 1). Trimebutine is an opioid antispasmodic that has been used to treat a range of gastrointestinal conditions, including irritable bowel syndrome, for over 40 years. Shown to be safe in a Phase I clinical trial (ClinicalTrials.gov identifier: NCT01738425), this agent is now in Phase II clinical trials as a pre-colonoscopy analgesic (ClinicalTrials.gov identifier: NCT01926444 and NCT02276768).

Several $\mathrm{H}_{2} \mathrm{~S}$-based therapeutics target disorders that are characterized by oxidative stress and associated tissue injury [12]. Based on these observations, zerovalent sulfur (SG-1002 Fig $5 \mathrm{C}$, Table 1) is being developed as a medicinal food, with the initial aim of targeting heart 
failure [109]. Preclinical studies in relevant animal models of heart failure have confirmed that SG-1002 is effective in decreasing infarct size, improving cardiac function, increasing angiogenesis, decreasing inflammation and downregulating oxidative stress after infarction. A Phase I trial of SG-1002 (ClinicalTrials.gov identifier: NCT02278276) evaluated doses of $200 \mathrm{mg}, 400 \mathrm{mg}$ and $800 \mathrm{mg}$ per day in healthy volunteers and reported dose-dependent increases in plasma $\mathrm{H}_{2} \mathrm{~S}$ levels, and only minor adverse effects. A second study has been designed (ClinicalTrials.gov identifier: NCT01989208) to evaluate the ability of SG-1002 to elevate plasma $\mathrm{H}_{2} \mathrm{~S}$ levels (in effect, reversing the defects in circulating $\mathrm{H}_{2} \mathrm{~S}$ ) and to reduce markers of oxidative stress and heart failure.

ATB-429 (Fig 4F, Table 1) is an $\mathrm{H}_{2} \mathrm{~S}$-releasing derivative of mesalamine and was developed with the notion that the $\mathrm{H}_{2} \mathrm{~S}$ released from the compound would provide additional antiinflammatory and ulcer-healing effects to those of mesalamine [336], which is used for treatment of Crohn's disease and ulcerative colitis. In one study, mice with hapten-induced colitis were treated orally twice daily with vehicle, mesalamine or ATB-429 [337]. After 3 days of treatment, there was a significant reduction in the colitis disease activity score and in tissue granulocyte numbers (myeloperoxidase activity), which was not seen with mesalamine.

\section{Inhibition CBS or CSE as a strategy to treat cancer}

In recent studies it has been shown that CBS was selectively overexpressed in colon cancer, and that $\mathrm{H}_{2} \mathrm{~S}$ produced by it served to maintain the tumor's cellular bioenergetics and to promote tumor angiogenesis $[98,105]$. In these studies the expression of the other two $\mathrm{H}_{2} \mathrm{~S}$ producing enzymes (CSE and 3-MST) was not up-regulated in the colorectal cancer cells or tumor tissue. In vitro, shRNA-mediated gene silencing of $C B S$ resulted in a significant inhibition of colon cancer cell proliferation; whereas $C S E$ silencing did not. Also in colon cancer tumor xenografts, shRNA-mediated knockdown of $C B S$ reduced the growth rate [98, 105]. Pharmacological inhibition of CBS with aminooxyacetic acid (AOAA) produced results very similar to gene silencing $[98,105]$. In vivo, AOAA inhibited growth of colon can cell xenografts and the growth of patient-derived tumor xenografts $[98,105]$.

When CBS in an ovarian cancer cell line was silenced by siRNA; that led to inhibition of cell proliferation and metastatic nodule formation [99]. Silencing $C B S$ reduced cellular GSH levels, impaired $\mathrm{H}_{2} \mathrm{~S}$ production, activated $\mathrm{p} 53$ and inhibited NF- $\mathrm{\kappa B}$. There was decreased mitochondrial oxygen consumption and increased ROS production. Collectively these results indicated that CBS was important in regulating the redox balance and metabolism of the ovarian cancer cells promoting tumor growth and metastasis. Human breast cancer (HBC) patient-derived tissue arrays and immunoblot analysis of HBC cells exhibited significantly increased levels of CBS when compared with their normal counterparts [101]. This was associated with increased levels of $\mathrm{H}_{2} \mathrm{~S}$ and cystathionine (CTH). Silencing of $C B S$ in HBC cells caused a significant decrease in the levels of $\mathrm{H}_{2} \mathrm{~S}$ and CTH. $C B S$-silenced cells exhibited significantly reduced growth in the presence of activated macrophages and in xenograft models. It has also been shown that human prostate cancer tissues and the androgen-dependent prostate cancer cell line LNCaP express high levels of CBS and CSE [100] which were down-regulated by dihydrotestosterone. It should be noted that normal 
prostatic epithelial cells (RWPE-1) did not show any CBS/CSE expression and androgenindependent prostate cancer cells (PC-3) expressed very low levels of CSE and no CBS levels [100].

There is very limited data on the functional and differential role of CSE and MST/ACT in cancer. Nevertheless there are some studies that have documented up-regulation of CSE and MST in several tumors. In a recent study it was shown that CSE was overexpressed in both human breast cancer tissues and breast cancer cell lines [338]. CSE knockdown suppressed the proliferation and migration of breast cancer cells while CSE overexpression promoted them. Furthermore, STAT3 expression positively correlated with CSE expression strongly suggesting that STAT3 could regulate CSE transcription. In human melanoma samples CSE expression was highest in primary tumors, decreased in the metastatic lesions and was almost silent in non-lymph node metastases [106]. Overexpression of CSE induced spontaneous apoptosis of human melanoma cells as did diallyl trisulfide a putative $\mathrm{H}_{2} \mathrm{~S}$ donor; mechanistically this was due to suppression of NF- $\mathrm{kB}$ activity and inhibition of AKT and extracellular signal-regulated kinase pathways. In one report, using human glioblastoma-astrocytoma U-87 MG and neuroblastoma SHSY5Y cell lines, MST expression and activity was reported to be higher compared to CBS and CSE [339], however, no functional determinations were made. Recently it was shown that the Wnt pathway at the transcriptional level regulated CSE gene expression [340] in colon cancer cells. Activating the Wnt pathway increased CSE mRNA and protein levels, while siRNAmediated silencing of $\beta$-catenin decreased CSE mRNA and protein levels. Knockdown of CSE by shRNA or its inhibition by PAG decreased SW480 cell (colon cancer cells that express high levels of $\beta$-catenin) proliferation, migration, and tumor growth in a xenograft medel.

It should be noted that not all of these enzymatic silencing leads to tumor regression. For example, CBS silencing increased tumor growth in a glioma model. shRNA silencing of $C B S$ in U87-MG human glioma cells decreased the latency time to rapid tumor xenograft growth and increased the incidence and volume of intracranial tumors [341]. CBS knockdown increased the expression of HIF2 $\alpha$ and target genes encoding angiopoietin-like 4 (ANGPTL4) and VEGF. HIF2a knockdown counteracted the stimulatory effect of CBS knockdown on ANGPTL4 and VEGF expression. Furthermore, in human glioma samples, decreased CBS expression was associated with increased ANGPTL4 and VEGF expression. Thus, decreased CBS expression in gliomas may promote tumorigenesis by increasing HIF2a expression.

\section{Induction of iNOS and/or CBS/CSE as a strategy to treat cancer}

In some circles this might be viewed as heresy, however, let us examine the data a little more closely. There are reports that L-arginine supplementation can reduce tumor occurrence and development in some tumor models, including chemically induced solid tumors, transplantable solid tumors, and human tumors. For example, colorectal cancer was induced in rats by weekly subcutaneous injections of the colonic procarcinogen 1,2dimethylhydrazine (DMH) [342]. One group received L-arginine in their of drinking water. The results show that tumor incidence and tumor burden were significantly reduced in 
arginine treated rats compared to DMH controls. In an in vitro study utilizing SW480 human colon cancer cells, L-arginine administration at similar or higher than physiological concentrations reduced the progression of colon cancer, with iNOS having a role in reducing angiogenesis [343]. Xenograft studies with the same cell line showed that L-arginine supplementation significantly lowered MMP-2, MMP-9 and VEGF receptor levels in tumors whereas tumor NO levels and spleen natural killer (NK) cell activities were higher compared to the control untreated group. Thus L-arginine treatment inhibited the progression of colon cancer in this model by increasing NO levels and consequently enhancing NK cell activity.

In a randomized, double-blind, placebo-controlled protocol consisting of 69 males and 51 females divided into two arms each of 60 patients with colorectal carcinoma (CRC) and 60 patients with colorectal adenoma (CRA), the subjects underwent colonoscopy with biopsy specimens taken from the tumor, paratumor mucosa (within $5 \mathrm{~cm}$ of the tumor), and normal mucosa ( $>10 \mathrm{~cm}$ distance from the tumor). Each group was randomly divided further into two groups of 30 patients each, a test group which was administered $30 \mathrm{~g}(120 \mathrm{~mL})$ of freshly prepared L-arginine orally once a day for 3 days and a control group where the Larginine was substituted with $5 \%$ glucose $(120 \mathrm{~mL})$. All subjects with CRC underwent radical surgical resection 3 days after treatment, whereas those with CRA underwent tumor resection by colonoscopy; tissue samples were obtained during the procedures [344]. The results showed that eNOS and nNOS were expressed in the normal and paratumor mucosa; but not in the tumor cells, whereas, the glandular cells in the normal and paratumor mucosa did not express iNOS. The tumor cells showed moderate expression for iNOS, which was significantly increased after treatment. Before treatment, serum NO levels in the patients with CRC were similar to those in the patients with CRA; however, after treatment, the values significantly increased in the CRC group with no significant changes in the CRA group. Thus L-arginine treatment blocked the formation and development of colorectal tumors, this effect correlated with the increased serum NO levels through iNOS induction.

High iNOS expression is associated with favorable prognoses in ovarian [242] and lung cancers [284]. Overexpression of iNOS by gene transfer in prostate and colon cancer cells produced enhanced amounts of NO increasing the sensitivity of these cells to cisplatininduced cell death [345] or to radiation therapy [346]. In a mouse model of thyroid cancer, iNOS overexpression inhibited tumorigenesis [347]. iNOS expressing pancreatic cancer cells did not produce tumors or metastases in xenograft mouse models due to NO upregulation and apoptosis [348]. Overexpressing iNOS by other means has also produced anti-cancer effects. Microencapsulation of iNOS expressing cells and delivering them to human colon and ovarian cancer xenografts led to increases in apoptosis [15]. Retroviral delivery of iNOS in mice produced slowly progressing tumors and fewer lung metastases than control mice transfected with iNOS-negative retrovirus [349]. Thus, therapeutic overexpression of iNOS within the tumor through gene therapy or other means may be a fruitful approach in treating some cancers.

To the best of my knowledge, I am not aware of any attempts or efforts in trying to induce any of the $\mathrm{H}_{2} \mathrm{~S}$-generating enzymes as has been done with iNOS. The focus has been on developing inhibitors of these enzymes. Perhaps at some point in the near future it would be 
worthwhile to see whether as in the case of iNOS, induction of CBS/CSE would inhibit tumorigenesis or not, at least in some cases?

\section{Concluding remarks and future directions}

Given the enormous potential of NO in various aspects of medicine, it is quite surprising that not many NO-releasing agents have reached the marketplace. In the cancer arena, the reasons for this apparent lack of progress are multifactorial but primarily are due to the focus that the scientific community has placed towards chemoprevention rather than chemotherapy. While chemoprevention is ideal, its achievement with drugs is an arduous task, as safety concerns are extremely important and testing for this via clinical trials may prove to be an impossibility. However, chemotherapy of an already developed cancer takes a different dimension with much more options. Case in point is the Phase-I clinical trials with NO-aspirin (NCX-4016) developed by NicOx (Sophia Antipolis, France) which confirmed its GI safety compared to aspirin and its efficacy to inhibit platelet aggregation [350-352]. However, its development as a chemopreventive drug in patients who are at high risk of developing colorectal cancer was terminated due to the putative genotoxicity of a potential metabolite [353]. Although the genotoxicity of this metabolite has not been confirmed by others or for that matter for the intact molecule, nevertheless the development of NCX-4016 as a chemopreventive agent was halted. Had the focus been on chemotreatment as a single agent alone or in combination with established chemotherapeutic agents, the outcome may have been quite different. Another NO-releasing NSAID, NO-naproxen (naproxcinod), which was being evaluated for treatment of knee and hip osteoarthritis [354-358] has completed Phase-III clinical trials. However, concerns by the FDA about its GI and cardiovascular safety for long-term use, did not lead to approval of the NDA application in 2010 without further studies [359].

$\mathrm{NO}$ and $\mathrm{H}_{2} \mathrm{~S}$ appear to have major roles in modulating cancer therapy resistance, and this in itself holds a great deal of promise in improving patient outcomes, thus targeted cancer therapy with NO- and $\mathrm{H}_{2} \mathrm{~S}$-based compounds is a feasible proposition. Organ-specific delivery of $\mathrm{NO}$ and $\mathrm{H}_{2} \mathrm{~S}$ is something that appears to be quite achievable in the near future and with that, the possibility of disease-specific $\mathrm{NO}$ and $\mathrm{H}_{2} \mathrm{~S}$ donors. Selective inducers/ inhibitors of the various $\mathrm{H}_{2} \mathrm{~S}$ generating enzymes, such as CBS/CSE, and/or iNOS offers yet another avenue for therapeutic applications and development. However, all of these scenarios/caveats have pros and cons. For example, selective inhibitors of CBS could potentially increase homocysteine levels and thus increase cardiovascular risks. iNOS specific inhibitors could induce immunosuppression. What is abundantly clear is that one size does not fit all and individual cases have to be assessed and evaluated on their own merits, what type of tumor, what is the immune status of the patient, etc.

Lately, most of the science in this arena appears to be directed towards silencing and/or inhibiting the key enzymes that generate $\mathrm{NO}$ and $\mathrm{H}_{2} \mathrm{~S}$ with some dismissing any potential value of inducing these enzymes that may prove useful in certain circumstances. This is reminiscent of the COX-2 era where its expression was deemed central to the carcinogenesis process and hence the inhibition of the eicosanoid pathway by traditional NSAIDs and coxibs was the driving force/mechanism by which these agents prevented tumorgenesis.

Biochem Pharmacol. Author manuscript; available in PMC 2019 March 01. 
Little attention if any was given to the non-COX targets affected by these agents. It took the withdrawal of Vioxx for the scientific community to pause and appreciate a new era beyond COX-2 and its inhibition in cancer [233, 360], déjà vu all over again.

\section{Acknowledgments}

Supported in part by the National Institutes of Health [R24 DA018055; R01GM123508].

\section{Abbreviations}

$1400 \mathrm{~W}$

3-MP

3-MST

ADT-OH

AG

AOAA

CAT

CBS

cGMP

COX-1

COX-2

CSE

DAO

DEA/NO-aspirin
$\mathrm{N}$-[[3-(aminomethyl)phenyl]methyl]-ethanimidamide

3-Mercaptopyruvate

3-Mercaptopyruvate sulfurtransferase

5-(4-hydroxyphenyl)-3H-1, 2-dithiole-3-thione

Aminoguanidine

Aminooxyacetic acid

Cysteine aminotransferase

Cystathionine $\beta$-synthase

Cyclic guanosine monophosphate

Cyclooxygenase-1

Cyclooxygenase-2

Cystathionine $\gamma$-lyase

D-amino acid oxidase

$\mathrm{O}^{2}$-(acetylsalicyloyloxymethyl)-1-(N,N-diethylamino)diazen-1- ium-1,2-diolate

Deoxygenated $\mathrm{Hb}$

1,2-Dithiole-3-thione

Endothelial nitric oxide synthase

Extracellular signal-regulated kinase

Glyceraldehyde 3-phosphate dehydrogenase

S-nitrosoglutathione

Hydrogen sulfide

Hemoglobin 


\begin{tabular}{|c|c|}
\hline HIF-1 & Hypoxia-inducible factor-1 \\
\hline iNOS & Inducible nitric oxide synthase \\
\hline IPA/NO-aspirin & $\begin{array}{l}\mathrm{O}^{2} \text {-(acetylsalicyloyloxymethyl)-1-(N-isopropylamino)- } \\
\text { diazen-1- ium-1,2-diolate }\end{array}$ \\
\hline JS-K & $\begin{array}{l}\mathrm{O}^{2} \text {-(2,4-Dinitrophenyl)1-[(4-thoxycarbonyl)piperazin-1- } \\
\text { yl]diazen-1-ium-1,2-diolate }\end{array}$ \\
\hline Keap1 & Kelch-like ECH-associated protein 1 \\
\hline L-NAME & N5-[imino(nitroamino)methyl]-L-ornithine methyl ester \\
\hline L-NMMA & Tilarginine ( $\mathrm{N}^{\mathrm{G}}$-Monomethyl-L-arginine) \\
\hline MAPK & Mitogen-activated protein kinase \\
\hline Mb & Myoglobin \\
\hline MetHb & Methemoglobin \\
\hline MPO & Myeloperoxidase \\
\hline NF- $x \mathbf{B}$ & $\begin{array}{l}\text { Nuclear factor kappa-light-chain-enhancer of activated B } \\
\text { cells }\end{array}$ \\
\hline nNOS & Neuronal nitric oxide synthase \\
\hline NO & Nitric oxide \\
\hline NOS & Nitric oxide synthase \\
\hline Nrf2 & Nuclear factor-like 2 \\
\hline NSAIDs & Nonsteroidal anti-inflammatory drugs \\
\hline PDE5A & Phosphodiesterase 5A \\
\hline PKG1a & Protein kinase G1a \\
\hline PLP & Pyridoxal $5^{\prime}$-phosphate \\
\hline PPG or PAG & DL-propargylglycine \\
\hline PTEN & Phosphatase and tensin homolog \\
\hline RNS & Reactive nitrogen species \\
\hline ROS & Reactive oxygen species \\
\hline RSNO & S-nitrosothiols \\
\hline RSSH & Persulfides \\
\hline sGC & Soluble guanylate cyclase \\
\hline
\end{tabular}

Biochem Pharmacol. Author manuscript; available in PMC 2019 March 01. 
SNAP

SNP

STAT3

TBZ

TRPA1

VDCC

VEGF
$S$-Nitroso- $N$-acetyl-penicillamine

Sodium nitroprusside

Signal transducer and activator of transcription 3

4-hydroxy benzothiazamide

Transient receptor potential ankyrin 1

Voltage-dependent $\mathrm{Ca}^{2+}$ channels

Vascular endothelial growth factor

\section{References}

1. Ignarro LJ, Buga GM, Wood KS, Byrns RE, Chaudhuri G. Endothelium-derived relaxing factor produced and released from artery and vein is nitric oxide. Proceedings of the National Academy of Sciences of the United States of America. 1987; 84:9265-9. [PubMed: 2827174]

2. Hattori Y, Kasai K, Gross SS. NO suppresses while peroxynitrite sustains NF-kappaB: a paradigm to rationalize cytoprotective and cytotoxic actions attributed to NO. Cardiovasc Res. 2004; 63:3140. [PubMed: 15194459]

3. Katsuyama K, Shichiri M, Marumo F, Hirata Y. NO inhibits cytokine-induced iNOS expression and NF-kappaB activation by interfering with phosphorylation and degradation of IkappaB-alpha. Arterioscler Thromb Vasc Biol. 1998; 18:1796-802. [PubMed: 9812920]

4. Hogaboam CM, Befus AD, Wallace JL. Modulation of rat mast cell reactivity by IL-1 beta. Divergent effects on nitric oxide and platelet-activating factor release. J Immunol. 1993; 151:376774. [PubMed: 8397260]

5. Huang JQ, Sridhar S, Chen Y, Hunt RH. Meta-analysis of the relationship between helicobacter pylori seropositivity and gastric cancer. Gastroenterology. 1998; 114:1169-79. [PubMed: 9609753]

6. Naseem KM. The role of nitric oxide in cardiovascular diseases. Mol Aspects Med. 2005; 26:33-65. [PubMed: 15722114]

7. Wallace JL, Miller MJ. Nitric oxide in mucosal defense: a little goes a long way. Gastroenterology. 2000; 119:512-20. [PubMed: 10930387]

8. Wallace JL, Viappiani S, Bolla M. Cyclooxygenase-inhibiting nitric oxide donators for osteoarthritis. Trends Pharmacol Sci. 2009; 30:112-7. [PubMed: 19230986]

9. Abe K, Kimura H. The possible role of hydrogen sulfide as an endogenous neuromodulator. The Journal of neuroscience : the official journal of the Society for Neuroscience. 1996; 16:1066-71. [PubMed: 8558235]

10. Wang R. Two's company, three's a crowd: can H2S be the third endogenous gaseous transmitter? FASEB journal : official publication of the Federation of American Societies for Experimental Biology. 2002; 16:1792-8. [PubMed: 12409322]

11. Zhao W, Zhang J, Lu Y, Wang R. The vasorelaxant effect of $\mathrm{H}(2) \mathrm{S}$ as a novel endogenous gaseous K(ATP) channel opener. The EMBO journal. 2001; 20:6008-16. [PubMed: 11689441]

12. Elrod JW, Calvert JW, Morrison J, Doeller JE, Kraus DW, Tao L, et al. Hydrogen sulfide attenuates myocardial ischemia-reperfusion injury by preservation of mitochondrial function. Proceedings of the National Academy of Sciences of the United States of America. 2007; 104:15560-5. [PubMed: 17878306]

13. Zanardo RC, Brancaleone V, Distrutti E, Fiorucci S, Cirino G, Wallace JL. Hydrogen sulfide is an endogenous modulator of leukocyte-mediated inflammation. FASEB journal : official publication of the Federation of American Societies for Experimental Biology. 2006; 20:2118-20. [PubMed: 16912151]

14. Wallace JL, Ferraz JG, Muscara MN. Hydrogen sulfide: an endogenous mediator of resolution of inflammation and injury. Antioxidants \& redox signaling. 2012; 17:58-67. [PubMed: 22017247] 
15. Xu W, Liu LZ, Loizidou M, Ahmed M, Charles IG. The role of nitric oxide in cancer. Cell research. 2002; 12:311-20. [PubMed: 12528889]

16. Ridnour LA, Thomas DD, Donzelli S, Espey MG, Roberts DD, Wink DA, et al. The biphasic nature of nitric oxide responses in tumor biology. Antioxidants \& redox signaling. 2006; 8:132937. [PubMed: 16910780]

17. Wink DA, Vodovotz Y, Laval J, Laval F, Dewhirst MW, Mitchell JB. The multifaceted roles of nitric oxide in cancer. Carcinogenesis. 1998; 19:711-21. [PubMed: 9635855]

18. Kashfi, K., Esmaili, M. NO-H2S-Releasing Chimeras as a Multifaceted Approach to Cancer Therapy. In: Bonavida, B., editor. Cancer Sensitizing Agents for Chemotherapy; Nitric Oxide (Donor/Induced) in Chemosensitization. Elsevier/Academic Press; 2017. p. 105-42.

19. Wallace JL. Hydrogen sulfide-releasing anti-inflammatory drugs. Trends Pharmacol Sci. 2007; 28:501-5. [PubMed: 17884186]

20. Li L, Bhatia M, Moore PK. Hydrogen sulphide--a novel mediator of inflammation? Curr Opin Pharmacol. 2006; 6:125-9. [PubMed: 16487749]

21. Bhatia M, Sidhapuriwala JN, Sparatore A, Moore PK. Treatment with H2S-releasing diclofenac protects mice against acute pancreatitis-associated lung injury. Shock (Augusta, Ga). 2008; 29:848.

22. Bhatia M, Wong FL, Fu D, Lau HY, Moochhala SM, Moore PK. Role of hydrogen sulfide in acute pancreatitis and associated lung injury. FASEB journal : official publication of the Federation of American Societies for Experimental Biology. 2005; 19:623-5. [PubMed: 15671155]

23. Tamizhselvi R, Moore PK, Bhatia M. Hydrogen sulfide acts as a mediator of inflammation in acute pancreatitis: in vitro studies using isolated mouse pancreatic acinar cells. J Cell Mol Med. 2007; 11:315-26. [PubMed: 17488480]

24. Szabo C. A timeline of hydrogen sulfide (H2S) research: From environmental toxin to biological mediator. Biochem Pharmacol. 2017

25. Kashfi, K., Duvalsaint, PL. Nitric oxide donors and therapeutic applications in cancer. In: Seabra, AB., editor. Nitric Oxide Donors: Novel Biomedical Applications. Oxford, United Kingdom: Elsevier/Academic Press; 2017. p. 75-119.

26. Motterlini R, Otterbein LE. The therapeutic potential of carbon monoxide. Nature reviews Drug discovery. 2010; 9:728-43. [PubMed: 20811383]

27. Tenhunen R, Marver HS, Schmid R. Microsomal heme oxygenase. Characterization of the enzyme. The Journal of biological chemistry. 1969; 244:6388-94. [PubMed: 4390967]

28. Foresti R, Motterlini R. The heme oxygenase pathway and its interaction with nitric oxide in the control of cellular homeostasis. Free radical research. 1999; 31:459-75. [PubMed: 10630670]

29. Otterbein LE, Choi AM. Heme oxygenase: colors of defense against cellular stress. American journal of physiology Lung cellular and molecular physiology. 2000; 279:L1029-37. [PubMed: 11076792]

30. Applegate LA, Luscher P, Tyrrell RM. Induction of heme oxygenase: a general response to oxidant stress in cultured mammalian cells. Cancer research. 1991; 51:974-8. [PubMed: 1988141]

31. Maines MD. The heme oxygenase system: a regulator of second messenger gases. Annu Rev Pharmacol Toxicol. 1997; 37:517-54. [PubMed: 9131263]

32. Mann, BE., Motterlini, R. Chemical communications (Cambridge, England). 2007. CO and NO in medicine; p. 4197-208.

33. Wu L, Wang R. Carbon monoxide: endogenous production, physiological functions, and pharmacological applications. Pharmacological reviews. 2005; 57:585-630. [PubMed: 16382109]

34. Szabo C. Gasotransmitters in cancer: from pathophysiology to experimental therapy. Nat Rev Drug Discov. 2016; 15:185-203. [PubMed: 26678620]

35. Olas B. Hydrogen sulfide in hemostasis: Friend or foe? Chemico-Biological Interactions. 2014; 217:49-56. [PubMed: 24746521]

36. Moncada S, Higgs A. The L-arginine-nitric oxide pathway. The New England journal of medicine. 1993; 329:2002-12. [PubMed: 7504210] 
37. Ignarro LJ. Endothelium-derived nitric oxide: actions and properties. FASEB journal : official publication of the Federation of American Societies for Experimental Biology. 1989; 3:31-6. [PubMed: 2642868]

38. Stuehr DJ. Structure-function aspects in the nitric oxide synthases. Annu Rev Pharmacol Toxicol. 1997; 37:339-59. [PubMed: 9131257]

39. Dimmeler S, Fleming I, Fisslthaler B, Hermann C, Busse R, Zeiher AM. Activation of nitric oxide synthase in endothelial cells by Akt-dependent phosphorylation. Nature. 1999; 399:601-5. [PubMed: 10376603]

40. Sessa WC. eNOS at a glance. Journal of cell science. 2004; 117:2427-9. [PubMed: 15159447]

41. Geller DA, Billiar TR. Molecular biology of nitric oxide synthases. Cancer metastasis reviews. 1998; 17:7-23. [PubMed: 9544420]

42. Alderton WK, Cooper CE, Knowles RG. Nitric oxide synthases: structure, function and inhibition. The Biochemical journal. 2001; 357:593-615. [PubMed: 11463332]

43. Friebe A, Koesling D. Regulation of nitric oxide-sensitive guanylyl cyclase. Circulation research. 2003; 93:96-105. [PubMed: 12881475]

44. Dangel O, Mergia E, Karlisch K, Groneberg D, Koesling D, Friebe A. Nitric oxide-sensitive guanylyl cyclase is the only nitric oxide receptor mediating platelet inhibition. Journal of thrombosis and haemostasis : JTH. 2010; 8:1343-52. [PubMed: 20149081]

45. Lincoln, T., Cornwell, T., Komalavilas, P., MacMillan-Crow, LA., Boerth, NJ. The nitric oxidecyclic GMP signaling system. In: MB, editor. Biochemistry of smooth muscle contraction. San Diego: Academic Press; 1996. p. 257-68.

46. Nathan C, Xie QW. Nitric oxide synthases: roles, tolls, and controls. Cell. 1994; 78:915-8. [PubMed: 7522969]

47. Kleinert H, Schwarz PM, Forstermann U. Regulation of the expression of inducible nitric oxide synthase. Biological chemistry. 2003; 384:1343-64. [PubMed: 14669979]

48. Michel T, Feron O. Nitric oxide synthases: which, where, how, and why? The Journal of clinical investigation. 1997; 100:2146-52. [PubMed: 9410890]

49. Kolios G, Valatas V, Ward SG. Nitric oxide in inflammatory bowel disease: a universal messenger in an unsolved puzzle. Immunology. 2004; 113:427-37. [PubMed: 15554920]

50. Goligorsky MS, Brodsky SV, Noiri E. NO bioavailability, endothelial dysfunction, and acute renal failure: new insights into pathophysiology. Seminars in nephrology. 2004; 24:316-23. [PubMed: 15252771]

51. Thomsen LL, Miles DW. Role of nitric oxide in tumour progression: lessons from human tumours. Cancer metastasis reviews. 1998; 17:107-18. [PubMed: 9544426]

52. Radomski MW, Jenkins DC, Holmes L, Moncada S. Human colorectal adenocarcinoma cells: differential nitric oxide synthesis determines their ability to aggregate platelets. Cancer research. 1991; 51:6073-8. [PubMed: 1718593]

53. Vannini F, Kashfi K, Nath N. The dual role of iNOS in cancer. Redox biology. 2015; 6:334-43. [PubMed: 26335399]

54. Jahani-Asl A, Bonni A. iNOS: a potential therapeutic target for malignant glioma. Current molecular medicine. 2013; 13:1241-9. [PubMed: 23590833]

55. Heinecke JL, Ridnour LA, Cheng RY, Switzer CH, Lizardo MM, Khanna C, et al. Tumor microenvironment-based feed-forward regulation of NOS2 in breast cancer progression. Proceedings of the National Academy of Sciences of the United States of America. 2014; 111:6323-8. [PubMed: 24733928]

56. Jenkins DC, Charles IG, Thomsen LL, Moss DW, Holmes LS, Baylis SA, et al. Roles of nitric oxide in tumor growth. Proceedings of the National Academy of Sciences of the United States of America. 1995; 92:4392-6. [PubMed: 7538668]

57. Granados-Principal S, Liu Y, Guevara ML, Blanco E, Choi DS, Qian W, et al. Inhibition of iNOS as a novel effective targeted therapy against triple-negative breast cancer. Breast cancer research : BCR. 2015; 17:25. [PubMed: 25849745]

58. Cosby K, Partovi KS, Crawford JH, Patel RP, Reiter CD, Martyr S, et al. Nitrite reduction to nitric oxide by deoxyhemoglobin vasodilates the human circulation. Nature medicine. 2003; 9:1498505. 
59. Kim-Shapiro DB, Gladwin MT. Mechanisms of nitrite bioactivation. Nitric oxide : biology and chemistry / official journal of the Nitric Oxide Society. 2014; 38:58-68.

60. Jeffers A, Xu X, Huang KT, Cho M, Hogg N, Patel RP, et al. Hemoglobin mediated nitrite activation of soluble guanylyl cyclase. Comparative biochemistry and physiology Part A, Molecular \& integrative physiology. 2005; 142:130-5.

61. Gow AJ. Nitric oxide, hemoglobin, and hypoxic vasodilation. American journal of respiratory cell and molecular biology. 2005; 32:479-82. [PubMed: 15901617]

62. Basu S, Grubina R, Huang J, Conradie J, Huang Z, Jeffers A, et al. Catalytic generation of N2O3 by the concerted nitrite reductase and anhydrase activity of hemoglobin. Nature chemical biology. 2007; 3:785-94. [PubMed: 17982448]

63. Nagababu E, Ramasamy S, Rifkind JM. S-nitrosohemoglobin: a mechanism for its formation in conjunction with nitrite reduction by deoxyhemoglobin. Nitric oxide : biology and chemistry / official journal of the Nitric Oxide Society. 2006; 15:20-9.

64. Angelo M, Singel DJ, Stamler JS. An S-nitrosothiol (SNO) synthase function of hemoglobin that utilizes nitrite as a substrate. Proceedings of the National Academy of Sciences of the United States of America. 2006; 103:8366-71. [PubMed: 16717191]

65. Patel RP, Hogg N, Kim-Shapiro DB. The potential role of the red blood cell in nitrite-dependent regulation of blood flow. Cardiovasc Res. 2011; 89:507-15. [PubMed: 20952416]

66. Shiva S, Huang Z, Grubina R, Sun J, Ringwood LA, MacArthur PH, et al. Deoxymyoglobin is a nitrite reductase that generates nitric oxide and regulates mitochondrial respiration. Circulation research. 2007; 100:654-61. [PubMed: 17293481]

67. Hendgen-Cotta UB, Merx MW, Shiva S, Schmitz J, Becher S, Klare JP, et al. Nitrite reductase activity of myoglobin regulates respiration and cellular viability in myocardial ischemiareperfusion injury. Proceedings of the National Academy of Sciences of the United States of America. 2008; 105:10256-61. [PubMed: 18632562]

68. Totzeck M, Hendgen-Cotta UB, Luedike P, Berenbrink M, Klare JP, Steinhoff HJ, et al. Nitrite regulates hypoxic vasodilation via myoglobin-dependent nitric oxide generation. Circulation. 2012; 126:325-34. [PubMed: 22685116]

69. Lipton SA, Choi YB, Pan ZH, Lei SZ, Chen HS, Sucher NJ, et al. A redox-based mechanism for the neuroprotective and neurodestructive effects of nitric oxide and related nitroso-compounds. Nature. 1993; 364:626-32. [PubMed: 8394509]

70. Stamler JS. Redox signaling: nitrosylation and related target interactions of nitric oxide. Cell. 1994; 78:931-6. [PubMed: 7923362]

71. Stamler JS, Singel DJ, Loscalzo J. Biochemistry of nitric oxide and its redox-activated forms. Science (New York, NY). 1992; 258:1898-902.

72. Broillet MC. S-nitrosylation of proteins. Cellular and molecular life sciences : CMLS. 1999; 55:1036-42. [PubMed: 10442087]

73. Hess DT, Matsumoto A, Kim SO, Marshall HE, Stamler JS. Protein S-nitrosylation: purview and parameters. Nature reviews Molecular cell biology. 2005; 6:150-66. [PubMed: 15688001]

74. Liu H, Colavitti R, Rovira II, Finkel T. Redox-dependent transcriptional regulation. Circulation research. 2005; 97:967-74. [PubMed: 16284189]

75. Leon-Bollotte L, Subramaniam S, Cauvard O, Plenchette-Colas S, Paul C, Godard C, et al. Snitrosylation of the death receptor fas promotes fas ligand-mediated apoptosis in cancer cells. Gastroenterology. 2011; 140:2009-18. 18e1-4. [PubMed: 21354149]

76. Tang Z, Bauer JA, Morrison B, Lindner DJ. Nitrosylcobalamin promotes cell death via S nitrosylation of Apo2L/TRAIL receptor DR4. Molecular and cellular biology. 2006; 26:5588-94. [PubMed: 16847314]

77. Glynn SA, Boersma BJ, Dorsey TH, Yi M, Yfantis HG, Ridnour LA, et al. Increased NOS2 predicts poor survival in estrogen receptor-negative breast cancer patients. The Journal of clinical investigation. 2010; 120:3843-54. [PubMed: 20978357]

78. Ducrocq C, Blanchard B, Pignatelli B, Ohshima H. Peroxynitrite: an endogenous oxidizing and nitrating agent. Cellular and molecular life sciences : CMLS. 1999; 55:1068-77. [PubMed: 10442088] 
79. Szabo C, Ischiropoulos H, Radi R. Peroxynitrite: biochemistry, pathophysiology and development of therapeutics. Nature reviews Drug discovery. 2007; 6:662-80. [PubMed: 17667957]

80. Seregelyes C, Igamberdiev AU, Maassen A, Hennig J, Dudits D, Hill RD. NO-degradation by alfalfa class 1 hemoglobin (Mhb1): a possible link to PR-1a gene expression in Mhb1overproducing tobacco plants. FEBS letters. 2004; 571:61-6. [PubMed: 15280018]

81. Kashfi K, Olson KR. Biology and therapeutic potential of hydrogen sulfide and hydrogen sulfidereleasing chimeras. Biochem Pharmacol. 2012; 24:019.

82. Bukovska G, Kery V, Kraus JP. Expression of human cystathionine beta-synthase in Escherichia coli: purification and characterization. Protein Expr Purif. 1994; 5:442-8. [PubMed: 7827502]

83. Erickson PF, Maxwell IH, Su LJ, Baumann M, Glode LM. Sequence of cDNA for rat cystathionine gamma-lyase and comparison of deduced amino acid sequence with related Escherichia coli enzymes. The Biochemical journal. 1990; 269:335-40. [PubMed: 2201285]

84. Shibuya N, Tanaka M, Yoshida M, Ogasawara Y, Togawa T, Ishii K, et al. 3-Mercaptopyruvate sulfurtransferase produces hydrogen sulfide and bound sulfane sulfur in the brain. Antioxidants \& redox signaling. 2009; 11:703-14. [PubMed: 18855522]

85. Paul BD, Snyder SH. H2S: A Novel Gasotransmitter that Signals by Sulfhydration. Trends in biochemical sciences. 2015; 40:687-700. [PubMed: 26439534]

86. Sen N, Paul BD, Gadalla MM, Mustafa AK, Sen T, Xu R, et al. Hydrogen sulfide-linked sulfhydration of NF-kappaB mediates its antiapoptotic actions. Molecular cell. 2012; 45:13-24. [PubMed: 22244329]

87. Zhu XY, Liu SJ, Liu YJ, Wang S, Ni X. Glucocorticoids suppress cystathionine gamma-lyase expression and $\mathrm{H} 2 \mathrm{~S}$ production in lipopolysaccharide-treated macrophages. Cellular and molecular life sciences : CMLS. 2010; 67:1119-32. [PubMed: 20063035]

88. Hine C, Harputlugil E, Zhang Y, Ruckenstuhl C, Lee BC, Brace L, et al. Endogenous hydrogen sulfide production is essential for dietary restriction benefits. Cell. 2015; 160:132-44. [PubMed: 25542313]

89. Krishnan N, Fu C, Pappin DJ, Tonks NK. H2S-Induced sulfhydration of the phosphatase PTP1B and its role in the endoplasmic reticulum stress response. Science signaling. 2011; 4:ra86. [PubMed: 22169477]

90. Westley AM, Westley J. Biological sulfane sulfur. Anal Biochem. 1991; 195:63-7. [PubMed: 1888018]

91. Searcy DG, Lee SH. Sulfur reduction by human erythrocytes. J Exp Zool. 1998; 282:310-22. [PubMed: 9755482]

92. Kolluru GK, Shen X, Kevil CG. A tale of two gases: NO and H2S, foes or friends for life? Redox biology. 2013; 1:313-8. [PubMed: 24024166]

93. Olson KR. H2S and polysulfide metabolism: Conventional and unconventional pathways. Biochem Pharmacol. 2017

94. Shibuya N, Koike S, Tanaka M, Ishigami-Yuasa M, Kimura Y, Ogasawara Y, et al. A novel pathway for the production of hydrogen sulfide from D-cysteine in mammalian cells. Nature communications. 2013; 4:1366.

95. Shibuya N, Kimura H. Production of hydrogen sulfide from d-cysteine and its therapeutic potential. Frontiers in endocrinology. 2013; 4:87. [PubMed: 23882260]

96. Gould SJ, Keller GA, Subramani S. Identification of peroxisomal targeting signals located at the carboxy terminus of four peroxisomal proteins. The Journal of cell biology. 1988; 107:897-905. [PubMed: 2901422]

97. Kimura H. Signaling of hydrogen sulfide and polysulfides. Antioxidants \& redox signaling. 2015; 22:347-9. [PubMed: 25178405]

98. Szabo C, Coletta C, Chao C, Modis K, Szczesny B, Papapetropoulos A, et al. Tumor-derived hydrogen sulfide, produced by cystathionine-beta-synthase, stimulates bioenergetics, cell proliferation, and angiogenesis in colon cancer. Proceedings of the National Academy of Sciences of the United States of America. 2013; 110:12474-9. [PubMed: 23836652]

99. Bhattacharyya S, Saha S, Giri K, Lanza IR, Nair KS, Jennings NB, et al. Cystathionine betasynthase (CBS) contributes to advanced ovarian cancer progression and drug resistance. PloS one. 2013; 8:e79167. [PubMed: 24236104] 
100. Guo H, Gai JW, Wang Y, Jin HF, Du JB, Jin J. Characterization of hydrogen sulfide and its synthases, cystathionine beta-synthase and cystathionine gamma-lyase, in human prostatic tissue and cells. Urology. 2012; 79:483e1-5.

101. Sen S, Kawahara B, Gupta D, Tsai R, Khachatryan M, Roy-Chowdhuri S, et al. Role of cystathionine beta-synthase in human breast Cancer. Free radical biology \& medicine. 2015; 86:228-38. [PubMed: 26051168]

102. Vellecco V, Mancini A, Ianaro A, Calderone V, Attanasio C, Cantalupo A, et al. Cystathionine beta-synthase-derived hydrogen sulfide is involved in human malignant hyperthermia. Clinical science (London, England : 1979). 2016; 130:35-44.

103. De Vos J, Thykjaer T, Tarte K, Ensslen M, Raynaud P, Requirand G, et al. Comparison of gene expression profiling between malignant and normal plasma cells with oligonucleotide arrays. Oncogene. 2002; 21:6848-57. [PubMed: 12360412]

104. Hellmich MR, Szabo C. Hydrogen Sulfide and Cancer. Handbook of experimental pharmacology. 2015; 230:233-41. [PubMed: 26162838]

105. Hellmich MR, Coletta C, Chao C, Szabo C. The therapeutic potential of cystathionine betasynthetase/hydrogen sulfide inhibition in cancer. Antioxidants \& redox signaling. 2015; 22:42448. [PubMed: 24730679]

106. Panza E, De Cicco P, Armogida C, Scognamiglio G, Gigantino V, Botti G, et al. Role of the cystathionine gamma lyase/hydrogen sulfide pathway in human melanoma progression. Pigment cell \& melanoma research. 2015; 28:61-72. [PubMed: 25205294]

107. Jurkowska H, Placha W, Nagahara N, Wrobel M. The expression and activity of cystathioninegamma-lyase and 3-mercaptopyruvate sulfurtransferase in human neoplastic cell lines. Amino acids. 2011; 41:151-8. [PubMed: 20446008]

108. Tang G, Wu L, Liang W, Wang R. Direct stimulation of K(ATP) channels by exogenous and endogenous hydrogen sulfide in vascular smooth muscle cells. Molecular pharmacology. 2005; 68:1757-64. [PubMed: 16150926]

109. Wallace JL, Wang R. Hydrogen sulfide-based therapeutics: exploiting a unique but ubiquitous gasotransmitter. Nature reviews Drug discovery. 2015; 14:329-45. [PubMed: 25849904]

110. Tang G, Zhang L, Yang G, Wu L, Wang R. Hydrogen sulfide-induced inhibition of L-type Ca2+ channels and insulin secretion in mouse pancreatic beta cells. Diabetologia. 2013; 56:533-41. [PubMed: 23275972]

111. Zhang R, Sun Y, Tsai H, Tang C, Jin H, Du J. Hydrogen sulfide inhibits L-type calcium currents depending upon the protein sulfhydryl state in rat cardiomyocytes. PloS one. 2012; 7:e37073. [PubMed: 22590646]

112. Sekiguchi F, Miyamoto Y, Kanaoka D, Ide H, Yoshida S, Ohkubo T, et al. Endogenous and exogenous hydrogen sulfide facilitates T-type calcium channel currents in Cav3. 2-expressing HEK293 cells. Biochemical and biophysical research communications. 2014; 445:225-9. [PubMed: 24508802]

113. Maeda Y, Aoki Y, Sekiguchi F, Matsunami M, Takahashi T, Nishikawa H, et al. Hyperalgesia induced by spinal and peripheral hydrogen sulfide: evidence for involvement of Cav3. 2 T-type calcium channels. Pain. 2009; 142:127-32. [PubMed: 19167819]

114. Hughes MN, Centelles MN, Moore KP. Making and working with hydrogen sulfide: The chemistry and generation of hydrogen sulfide in vitro and its measurement in vivo: a review. Free Radic Biol Med. 2009; 47:1346-53. [PubMed: 19770036]

115. Chen KY, Morris JC. Oxidation of sulfide by O2: catalysis and inhibition. Journal of Sanitation Engineering Division. 1972; 98:215-27.

116. Hildebrandt TM, Grieshaber MK. Three enzymatic activities catalyze the oxidation of sulfide to thiosulfate in mammalian and invertebrate mitochondria. FEBS J. 2008; 275:3352-61. [PubMed: 18494801]

117. Yong R, Searcy DG. Sulfide oxidation coupled to ATP synthesis in chicken liver mitochondria. Comparative biochemistry and physiology Part B, Biochemistry \& molecular biology. 2001; 129:129-37. 
118. Augustyn KD, Jackson MR, Jorns MS. Use of Tissue Metabolite Analysis and Enzyme Kinetics To Discriminate between Alternate Pathways for Hydrogen Sulfide Metabolism. Biochemistry. 2017; 56:986-96. [PubMed: 28107627]

119. Arp AJ, Childress JJ, Vetter RD. The sulphide-binding protein in the blood of the vestimentiferan tubeworm, Riftia pachyptila, is the extracellular hemoglobin. J Exp Biol. 1987; 128:139-58.

120. Wang R. Resurgence of carbon monoxide: an endogenous gaseous vasorelaxing factor. Canadian journal of physiology and pharmacology. 1998; 76:1-15. [PubMed: 9564544]

121. Wang R. Physiological implications of hydrogen sulfide: a whiff exploration that blossomed. Physiological reviews. 2012; 92:791-896. [PubMed: 22535897]

122. Nussbaum C, Klinke A, Adam M, Baldus S, Sperandio M. Myeloperoxidase: a leukocyte-derived protagonist of inflammation and cardiovascular disease. Antioxidants \& redox signaling. 2013; 18:692-713. [PubMed: 22823200]

123. Palinkas Z, Furtmuller PG, Nagy A, Jakopitsch C, Pirker KF, Magierowski M, et al. Interactions of hydrogen sulfide with myeloperoxidase. British journal of pharmacology. 2015; 172:1516-32. [PubMed: 24824874]

124. Grossi L. Hydrogen sulfide induces nitric oxide release from nitrite. Bioorganic \& medicinal chemistry letters. 2009; 19:6092-4. [PubMed: 19782565]

125. Wang R. Shared signaling pathways among gasotransmitters. Proceedings of the National Academy of Sciences of the United States of America. 2012; 109:8801-2. [PubMed: 22615409]

126. Lo Faro ML, Fox B, Whatmore JL, Winyard PG, Whiteman M. Hydrogen sulfide and nitric oxide interactions in inflammation. Nitric oxide : biology and chemistry / official journal of the Nitric Oxide Society. 2014; 41:38-47.

127. Taoka S, Banerjee R. Characterization of NO binding to human cystathionine beta-synthase: possible implications of the effects of $\mathrm{CO}$ and $\mathrm{NO}$ binding to the human enzyme. Journal of inorganic biochemistry. 2001; 87:245-51. [PubMed: 11744062]

128. Kubo S, Doe I, Kurokawa Y, Nishikawa H, Kawabata A. Direct inhibition of endothelial nitric oxide synthase by hydrogen sulfide: contribution to dual modulation of vascular tension. Toxicology. 2007; 232:138-46. [PubMed: 17276573]

129. Kubo S, Kurokawa Y, Doe I, Masuko T, Sekiguchi F, Kawabata A. Hydrogen sulfide inhibits activity of three isoforms of recombinant nitric oxide synthase. Toxicology. 2007; 241:92-7. [PubMed: 17888559]

130. Zhao W, Wang R. H(2)S-induced vasorelaxation and underlying cellular and molecular mechanisms. American journal of physiology Heart and circulatory physiology. 2002; 283:H474-80. [PubMed: 12124191]

131. Jeong SO, Pae HO, Oh GS, Jeong GS, Lee BS, Lee S, et al. Hydrogen sulfide potentiates interleukin-1beta-induced nitric oxide production via enhancement of extracellular signalregulated kinase activation in rat vascular smooth muscle cells. Biochemical and biophysical research communications. 2006; 345:938-44. [PubMed: 16707097]

132. Predmore BL, Julian D, Cardounel AJ. Hydrogen sulfide increases nitric oxide production from endothelial cells by an akt-dependent mechanism. Frontiers in physiology. 2011; 2:104. [PubMed: 22194727]

133. Kida M, Sugiyama T, Yoshimoto T, Ogawa Y. Hydrogen sulfide increases nitric oxide production with calcium-dependent activation of endothelial nitric oxide synthase in endothelial cells. European journal of pharmaceutical sciences : official journal of the European Federation for Pharmaceutical Sciences. 2013; 48:211-5. [PubMed: 23148920]

134. Altaany Z, Yang G, Wang R. Crosstalk between hydrogen sulfide and nitric oxide in endothelial cells. J Cell Mol Med. 2013; 17:879-88. [PubMed: 23742697]

135. Coletta C, Papapetropoulos A, Erdelyi K, Olah G, Modis K, Panopoulos P, et al. Hydrogen sulfide and nitric oxide are mutually dependent in the regulation of angiogenesis and endotheliumdependent vasorelaxation. Proceedings of the National Academy of Sciences of the United States of America. 2012; 109:9161-6. [PubMed: 22570497]

136. Whiteman M, Li L, Kostetski I, Chu SH, Siau JL, Bhatia M, et al. Evidence for the formation of a novel nitrosothiol from the gaseous mediators nitric oxide and hydrogen sulphide. Biochemical and biophysical research communications. 2006; 343:303-10. [PubMed: 16540095] 
137. Yong QC, Hu LF, Wang S, Huang D, Bian JS. Hydrogen sulfide interacts with nitric oxide in the heart: possible involvement of nitroxyl. Cardiovasc Res. 2010; 88:482-91. [PubMed: 20660605]

138. Filipovic MR, Miljkovic J, Nauser T, Royzen M, Klos K, Shubina T, et al. Chemical characterization of the smallest S-nitrosothiol, HSNO; cellular cross-talk of H2S and Snitrosothiols. Journal of the American Chemical Society. 2012; 134:12016-27. [PubMed: 22741609]

139. Miyamoto R, Koike S, Takano Y, Shibuya N, Kimura Y, Hanaoka K, et al. Polysulfides (H2Sn) produced from the interaction of hydrogen sulfide (H2S) and nitric oxide (NO) activate TRPA1 channels. Scientific reports. 2017; 7:45995. [PubMed: 28378773]

140. Kimura Y, Mikami Y, Osumi K, Tsugane M, Oka J, Kimura H. Polysulfides are possible H2Sderived signaling molecules in rat brain. FASEB journal : official publication of the Federation of American Societies for Experimental Biology. 2013; 27:2451-7. [PubMed: 23413359]

141. Hatakeyama Y, Takahashi K, Tominaga M, Kimura H, Ohta T. Polysulfide evokes acute pain through the activation of nociceptive TRPA1 in mouse sensory neurons. Molecular pain. 2015; 11:24. [PubMed: 25934637]

142. Koike S, Ogasawara Y, Shibuya N, Kimura H, Ishii K. Polysulfide exerts a protective effect against cytotoxicity caused by t-buthylhydroperoxide through Nrf2 signaling in neuroblastoma cells. FEBS letters. 2013; 587:3548-55. [PubMed: 24055470]

143. Greiner R, Palinkas Z, Basell K, Becher D, Antelmann H, Nagy P, et al. Polysulfides link H2S to protein thiol oxidation. Antioxidants \& redox signaling. 2013; 19:1749-65. [PubMed: 23646934]

144. Stubbert D, Prysyazhna O, Rudyk O, Scotcher J, Burgoyne JR, Eaton P. Protein kinase G Ialpha oxidation paradoxically underlies blood pressure lowering by the reductant hydrogen sulfide. Hypertension (Dallas, Tex : 1979). 2014; 64:1344-51.

145. Jarosz AP, Wei W, Gauld JW, Auld J, Ozcan F, Aslan M, et al. Glyceraldehyde 3-phosphate dehydrogenase (GAPDH) is inactivated by S-sulfuration in vitro. Free radical biology \& medicine. 2015; 89:512-21. [PubMed: 26453916]

146. Cortese-Krott MM, Fernandez BO, Santos JL, Mergia E, Grman M, Nagy P, et al. Nitrosopersulfide (SSNO(-)) accounts for sustained NO bioactivity of S-nitrosothiols following reaction with sulfide. Redox biology. 2014; 2:234-44. [PubMed: 24494198]

147. Cortese-Krott, MM., Kuhnle, GG., Dyson, A., Fernandez, BO., Grman, M., DuMond, JF., et al. Key bioactive reaction products of the $\mathrm{NO} / \mathrm{H} 2 \mathrm{~S}$ interaction are $\mathrm{S} / \mathrm{N}$-hybrid species, polysulfides, and nitroxyl. Proceedings of the National Academy of Sciences of the United States of America; 2015 ;

148. Ondrias K, Stasko A, Cacanyiova S, Sulova Z, Krizanova O, Kristek F, et al. H(2)S and HS(-) donor NaHS releases nitric oxide from nitrosothiols, metal nitrosyl complex, brain homogenate and murine L1210 leukaemia cells. Pflugers Archiv : European journal of physiology. 2008; 457:271-9. [PubMed: 18458940]

149. Cui S, Reichner JS, Mateo RB, Albina JE. Activated murine macrophages induce apoptosis in tumor cells through nitric oxide-dependent or -independent mechanisms. Cancer research. 1994; 54:2462-7. [PubMed: 8162595]

150. Brune B, von Knethen A, Sandau KB. Nitric oxide (NO): an effector of apoptosis. Cell death and differentiation. 1999; 6:969-75. [PubMed: 10556974]

151. Thomsen LL, Miles DW, Happerfield L, Bobrow LG, Knowles RG, Moncada S. Nitric oxide synthase activity in human breast cancer. British journal of cancer. 1995; 72:41-4. [PubMed: 7541238]

152. Basudhar D, Somasundaram V, de Oliveira GA, Kesarwala A, Heinecke JL, Cheng RY, et al. NOS2-derived NO Drives Multiple Pathways of Breast Cancer Progression. Antioxidants \& redox signaling. 2016

153. Klotz T, Bloch W, Volberg C, Engelmann U, Addicks K. Selective expression of inducible nitric oxide synthase in human prostate carcinoma. Cancer. 1998; 82:1897-903. [PubMed: 9587122]

154. Masri FA, Comhair SA, Koeck T, Xu W, Janocha A, Ghosh S, et al. Abnormalities in nitric oxide and its derivatives in lung cancer. American journal of respiratory and critical care medicine. 2005; 172:597-605. [PubMed: 15947282] 
155. Gallo O, Masini E, Morbidelli L, Franchi A, Fini-Storchi I, Vergari WA, et al. Role of nitric oxide in angiogenesis and tumor progression in head and neck cancer. J Natl Cancer Inst. 1998; 90:587-96. [PubMed: 9554441]

156. Ambs S, Merriam WG, Bennett WP, Felley-Bosco E, Ogunfusika MO, Oser SM, et al. Frequent nitric oxide synthase-2 expression in human colon adenomas: implication for tumor angiogenesis and colon cancer progression. Cancer research. 1998; 58:334-41. [PubMed: 9443414]

157. Lagares-Garcia JA, Moore RA, Collier B, Heggere M, Diaz F, Qian F. Nitric oxide synthase as a marker in colorectal carcinoma. The American surgeon. 2001; 67:709-13. [PubMed: 11450795]

158. Lechner M, Lirk P, Rieder J. Inducible nitric oxide synthase (iNOS) in tumor biology: the two sides of the same coin. Seminars in cancer biology. 2005; 15:277-89. [PubMed: 15914026]

159. Oronsky B, Fanger GR, Oronsky N, Knox S, Scicinski J. The implications of hyponitroxia in cancer. Translational oncology. 2014; 7:167-73. [PubMed: 24731473]

160. Fulton D, Gratton JP, Sessa WC. Post-translational control of endothelial nitric oxide synthase: why isn't calcium/calmodulin enough? The Journal of pharmacology and experimental therapeutics. 2001; 299:818-24. [PubMed: 11714864]

161. Ambs S, Hussain SP, Harris CC. Interactive effects of nitric oxide and the p53 tumor suppressor gene in carcinogenesis and tumor progression. FASEB journal : official publication of the Federation of American Societies for Experimental Biology. 1997; 11:443-8. [PubMed: 9194524]

162. Ridnour LA, Thomas DD, Switzer C, Flores-Santana W, Isenberg JS, Ambs S, et al. Molecular mechanisms for discrete nitric oxide levels in cancer. Nitric oxide : biology and chemistry / official journal of the Nitric Oxide Society. 2008; 19:73-6.

163. Li LM, Kilbourn RG, Adams J, Fidler IJ. Role of nitric oxide in lysis of tumor cells by cytokineactivated endothelial cells. Cancer research. 1991; 51:2531-5. [PubMed: 1902393]

164. Jiang H, Stewart CA, Fast DJ, Leu RW. Tumor target-derived soluble factor synergizes with IFNgamma and IL-2 to activate macrophages for tumor necrosis factor and nitric oxide production to mediate cytotoxicity of the same target. J Immunol. 1992; 149:2137-46. [PubMed: 1517576]

165. Xiao L, Eneroth PH, Qureshi GA. Nitric oxide synthase pathway may mediate human natural killer cell cytotoxicity. Scandinavian journal of immunology. 1995; 42:505-11. [PubMed: 7481553]

166. Fukumura D, Yonei Y, Kurose I, Saito H, Ohishi T, Higuchi H, et al. Role in nitric oxide in Kupffer cell-mediated hepatoma cell cytotoxicity in vitro and ex vivo. Hepatology (Baltimore, Md). 1996; 24:141-9.

167. Miller MR, Megson IL. Recent developments in nitric oxide donor drugs. British journal of pharmacology. 2007; 151:305-21. [PubMed: 17401442]

168. Choudhari SK, Chaudhary M, Bagde S, Gadbail AR, Joshi V. Nitric oxide and cancer: a review. World journal of surgical oncology. 2013; 11:118. [PubMed: 23718886]

169. Millet A, Bettaieb A, Renaud F, Prevotat L, Hammann A, Solary E, et al. Influence of the nitric oxide donor glyceryl trinitrate on apoptotic pathways in human colon cancer cells. Gastroenterology. 2002; 123:235-46. [PubMed: 12105852]

170. Trikha P, Sharma N, Athar M. Nitroglycerin: a NO donor inhibits TPA-mediated tumor promotion in murine skin. Carcinogenesis. 2001; 22:1207-11. [PubMed: 11470751]

171. Pipili-Synetos E, Papageorgiou A, Sakkoula E, Sotiropoulou G, Fotsis T, Karakiulakis G, et al. Inhibition of angiogenesis, tumour growth and metastasis by the NO-releasing vasodilators, isosorbide mononitrate and dinitrate. British journal of pharmacology. 1995; 116:1829-34. [PubMed: 8528567]

172. Tamano S, Ward JM, Diwan BA, Keefer LK, Weghorst CM, Calvert RJ, et al. Histogenesis and the role of p53 and K-ras mutations in hepatocarcinogenesis by glyceryl trinitrate (nitroglycerin) in male F344 rats. Carcinogenesis. 1996; 17:2477-86. [PubMed: 8968066]

173. Notas G, Xidakis C, Valatas V, Kouroumalis A, Kouroumalis E. Levels of circulating endothelin-1 and nitrates/nitrites in patients with virus-related hepatocellular carcinoma. Journal of viral hepatitis. 2001; 8:63-9. [PubMed: 11155153]

174. Muscat JE, Dyer AM, Rosenbaum RE, Rigas B. Nitric oxide-releasing medications and colorectal cancer risk: the framingham study. Anticancer research. 2005; 25:4471-4. [PubMed: 16334128] 
175. Dawber TR, Kannel WB, Lyell LP. An approach to longitudinal studies in a community: the Framingham Study. Annals of the New York Academy of Sciences. 1963; 107:539-56. [PubMed: 14025561]

176. Wei, G. The Framingham Heart Study (FHS) Project Period: 9/1/1948-5/1/2015. 2015.

177. Istvan ES, Deisenhofer J. Structural mechanism for statin inhibition of HMG-CoA reductase. Science (New York, NY). 2001; 292:1160-4.

178. Liao JK, Laufs U. Pleiotropic effects of statins. Annu Rev Pharmacol Toxicol. 2005; 45:89-118. [PubMed: 15822172]

179. Oesterle A, Laufs U, Liao JK. Pleiotropic Effects of Statins on the Cardiovascular System. Circulation research. 2017; 120:229-43. [PubMed: 28057795]

180. Gauthier TW, Scalia R, Murohara T, Guo JP, Lefer AM. Nitric oxide protects against leukocyteendothelium interactions in the early stages of hypercholesterolemia. Arterioscler Thromb Vasc Biol. 1995; 15:1652-9. [PubMed: 7583540]

181. Laufs U, Liao JK. Post-transcriptional regulation of endothelial nitric oxide synthase mRNA stability by Rho GTPase. The Journal of biological chemistry. 1998; 273:24266-71. [PubMed: 9727051]

182. Poynter JN, Gruber SB, Higgins PD, Almog R, Bonner JD, Rennert HS, et al. Statins and the risk of colorectal cancer. The New England journal of medicine. 2005; 352:2184-92. [PubMed: 15917383]

183. Jung YS, Park CH, Eun CS, Park DI, Han DS. Statin use and the risk of colorectal adenoma: A meta-analysis. Journal of gastroenterology and hepatology. 2016; 31:1823-30. [PubMed: 27043957]

184. Pikoulis E, Margonis GA, Angelou A, Zografos GC, Antoniou E. Statins in the chemoprevention of colorectal cancer in established animal models of sporadic and colitis-associated cancer. European journal of cancer prevention : the official journal of the European Cancer Prevention Organisation (ECP). 2016; 25:102-8. [PubMed: 25768976]

185. Muck AO, Seeger H, Wallwiener D. Inhibitory effect of statins on the proliferation of human breast cancer cells. International journal of clinical pharmacology and therapeutics. 2004; 42:695-700. [PubMed: 15624286]

186. Koyuturk M, Ersoz M, Altiok N. Simvastatin induces apoptosis in human breast cancer cells: p53 and estrogen receptor independent pathway requiring signalling through JNK. Cancer letters. 2007; 250:220-8. [PubMed: 17125918]

187. Ji Y, Rounds T, Crocker A, Sussman B, Hovey RC, Kingsley F, et al. The Effect of Atorvastatin on Breast Cancer Biomarkers in High-Risk Women. Cancer prevention research (Philadelphia, Pa). 2016; 9:379-84.

188. Vallianou NG, Kostantinou A, Kougias M, Kazazis C. Statins and cancer. Anticancer Agents Med Chem. 2014; 14:706-12. [PubMed: 24295174]

189. Sivaprasad U, Abbas T, Dutta A. Differential efficacy of 3-hydroxy-3-methylglutaryl CoA reductase inhibitors on the cell cycle of prostate cancer cells. Molecular cancer therapeutics. 2006; 5:2310-6. [PubMed: 16985065]

190. Campbell MJ, Esserman LJ, Zhou Y, Shoemaker M, Lobo M, Borman E, et al. Breast cancer growth prevention by statins. Cancer research. 2006; 66:8707-14. [PubMed: 16951186]

191. Kusama T, Mukai M, Iwasaki T, Tatsuta M, Matsumoto Y, Akedo H, et al. Inhibition of epidermal growth factor-induced RhoA translocation and invasion of human pancreatic cancer cells by 3hydroxy-3-methylglutaryl-coenzyme a reductase inhibitors. Cancer research. 2001; 61:4885-91. [PubMed: 11406567]

192. Kusama T, Mukai M, Iwasaki T, Tatsuta M, Matsumoto Y, Akedo H, et al. 3-hydroxy-3methylglutaryl-coenzyme a reductase inhibitors reduce human pancreatic cancer cell invasion and metastasis. Gastroenterology. 2002; 122:308-17. [PubMed: 11832446]

193. Paragh G, Kertai P, Kovacs P, Paragh G Jr, Fulop P, Foris G. HMG CoA reductase inhibitor fluvastatin arrests the development of implanted hepatocarcinoma in rats. Anticancer Res. 2003; 23:3949-54. [PubMed: 14666702] 
194. Kotamraju S, Williams CL, Kalyanaraman B. Statin-induced breast cancer cell death: role of inducible nitric oxide and arginase-dependent pathways. Cancer research. 2007; 67:7386-94. [PubMed: 17671209]

195. Bhatia M, Sidhapuriwala J, Moochhala SM, Moore PK. Hydrogen sulphide is a mediator of carrageenan-induced hindpaw oedema in the rat. British journal of pharmacology. 2005; 145:141-4. [PubMed: 15753944]

196. Li L, Bhatia M, Zhu YZ, Zhu YC, Ramnath RD, Wang ZJ, et al. Hydrogen sulfide is a novel mediator of lipopolysaccharide-induced inflammation in the mouse. FASEB journal : official publication of the Federation of American Societies for Experimental Biology. 2005; 19:1196-8. [PubMed: 15863703]

197. Anuar F, Whiteman M, Siau JL, Kwong SE, Bhatia M, Moore PK. Nitric oxide-releasing flurbiprofen reduces formation of proinflammatory hydrogen sulfide in lipopolysaccharidetreated rat. British journal of pharmacology. 2006; 147:966-74. [PubMed: 16491094]

198. Anuar F, Whiteman M, Bhatia M, Moore PK. Flurbiprofen and its nitric oxide-releasing derivative protect against septic shock in rats. Inflamm Res. 2006; 55:498-503. [PubMed: 17122968]

199. Whiteman M, Armstrong JS, Chu SH, Jia-Ling S, Wong BS, Cheung NS, et al. The novel neuromodulator hydrogen sulfide: an endogenous peroxynitrite 'scavenger'? J Neurochem. 2004; 90:765-8. [PubMed: 15255956]

200. Whiteman M, Cheung NS, Zhu YZ, Chu SH, Siau JL, Wong BS, et al. Hydrogen sulphide: a novel inhibitor of hypochlorous acid-mediated oxidative damage in the brain? Biochemical and biophysical research communications. 2005; 326:794-8. [PubMed: 15607739]

201. Mariggio MA, Minunno V, Riccardi S, Santacroce R, De Rinaldis P, Fumarulo R. Sulfide enhancement of PMN apoptosis. Immunopharmacol Immunotoxicol. 1998; 20:399-408. [PubMed: 9736444]

202. Gilroy DW, Lawrence T, Perretti M, Rossi AG. Inflammatory resolution: new opportunities for drug discovery. Nature reviews Drug discovery. 2004; 3:401-16. [PubMed: 15136788]

203. Hu LF, Wong PT, Moore PK, Bian JS. Hydrogen sulfide attenuates lipopolysaccharide-induced inflammation by inhibition of p38 mitogen-activated protein kinase in microglia. J Neurochem. 2007; 100:1121-8. [PubMed: 17212697]

204. Hu LF, Lu M, Wu ZY, Wong PT, Bian JS. Hydrogen sulfide inhibits rotenone-induced apoptosis via preservation of mitochondrial function. Molecular pharmacology. 2009; 75:27-34. [PubMed: 18832435]

205. Aranda E, Lopez-Pedrera C, De La Haba-Rodriguez JR, Rodriguez-Ariza A. Nitric oxide and cancer: the emerging role of S-nitrosylation. Current molecular medicine. 2012; 12:50-67. [PubMed: 22082481]

206. Quirke P, Durdey P, Dixon MF, Williams NS. Local recurrence of rectal adenocarcinoma due to inadequate surgical resection. Histopathological study of lateral tumour spread and surgical excision. Lancet (London, England). 1986; 2:996-9.

207. Krishna MC, English S, Yamada K, Yoo J, Murugesan R, Devasahayam N, et al. Overhauser enhanced magnetic resonance imaging for tumor oximetry: coregistration of tumor anatomy and tissue oxygen concentration. Proceedings of the National Academy of Sciences of the United States of America. 2002; 99:2216-21. [PubMed: 11854518]

208. Vaupel P, Schlenger K, Knoop C, Hockel M. Oxygenation of human tumors: evaluation of tissue oxygen distribution in breast cancers by computerized $\mathrm{O} 2$ tension measurements. Cancer research. 1991; 51:3316-22. [PubMed: 2040005]

209. Dewey DL. Effect of oxygen and nitric oxide on the radio-sensitivity of human cells in tissue culture. Nature. 1960; 186:780-2. [PubMed: 13816318]

210. Stewart GD, Nanda J, Katz E, Bowman KJ, Christie JG, Brown DJ, et al. DNA strand breaks and hypoxia response inhibition mediate the radiosensitisation effect of nitric oxide donors on prostate cancer under varying oxygen conditions. Biochem Pharmacol. 2011; 81:203-10. [PubMed: 20888325] 
211. Cook T, Wang Z, Alber S, Liu K, Watkins SC, Vodovotz Y, et al. Nitric oxide and ionizing radiation synergistically promote apoptosis and growth inhibition of cancer by activating p53. Cancer research. 2004; 64:8015-21. [PubMed: 15520210]

212. Bonavida, B. Nitric Oxide Donors Sensitize Resistant Cancer Cells to Apoptosis Induced by Chemotherapy: Molecular Mechanisms of Sensitization. In: Bonavida, B., editor. Cancer Sensitizing Agents for Chemotherapy; Nitric Oxide (Donor/Induced) in Chemosensitization. Elsevier/Academic Press; 2017. p. 15-34.

213. Holohan C, Van Schaeybroeck S, Longley DB, Johnston PG. Cancer drug resistance: an evolving paradigm. Nature reviews Cancer. 2013; 13:714-26. [PubMed: 24060863]

214. Longley DB, Johnston PG. Molecular mechanisms of drug resistance. The Journal of pathology. 2005; 205:275-92. [PubMed: 15641020]

215. Riganti C, Miraglia E, Viarisio D, Costamagna C, Pescarmona G, Ghigo D, et al. Nitric oxide reverts the resistance to doxorubicin in human colon cancer cells by inhibiting the drug efflux. Cancer research. 2005; 65:516-25. [PubMed: 15695394]

216. Gottesman MM, Fojo T, Bates SE. Multidrug resistance in cancer: role of ATP-dependent transporters. Nature reviews Cancer. 2002; 2:48-58. [PubMed: 11902585]

217. Simon SM, Schindler M. Cell biological mechanisms of multidrug resistance in tumors. Proceedings of the National Academy of Sciences of the United States of America. 1994; 91:3497-504. [PubMed: 7909602]

218. Evig CB, Kelley EE, Weydert CJ, Chu Y, Buettner GR, Burns CP. Endogenous production and exogenous exposure to nitric oxide augment doxorubicin cytotoxicity for breast cancer cells but not cardiac myoblasts. Nitric oxide : biology and chemistry / official journal of the Nitric Oxide Society. 2004; 10:119-29.

219. Huerta-Yepez S, Baritaki S, Baay-Guzman G, Hernandez-Luna MA, Hernandez-Cueto A, Vega MI, et al. Contribution of either YY1 or BclXL-induced inhibition by the NO-donor DETANONOate in the reversal of drug resistance, both in vitro and in vivo. YY1 and BclXL are overexpressed in prostate cancer. Nitric oxide : biology and chemistry / official journal of the Nitric Oxide Society. 2013; 29:17-24.

220. Huerta-Yepez S, Vega M, Jazirehi A, Garban H, Hongo F, Cheng G, et al. Nitric oxide sensitizes prostate carcinoma cell lines to TRAIL-mediated apoptosis via inactivation of NF-kappa B and inhibition of Bcl-xl expression. Oncogene. 2004; 23:4993-5003. [PubMed: 15048072]

221. Marshall HE, Hess DT, Stamler JS. S-nitrosylation: physiological regulation of NF-kappaB. Proceedings of the National Academy of Sciences of the United States of America. 2004; 101:8841-2. [PubMed: 15187230]

222. Kashfi K, Borgo S, Williams JL, Chen J, Gao J, Glekas A, et al. Positional isomerism markedly affects the growth inhibition of colon cancer cells by nitric oxide-donating aspirin in vitro and in vivo. The Journal of pharmacology and experimental therapeutics. 2005; 312:978-88. [PubMed: 15528453]

223. Bratasz A, Weir NM, Parinandi NL, Zweier JL, Sridhar R, Ignarro LJ, et al. Reversal to cisplatin sensitivity in recurrent human ovarian cancer cells by NCX-4016, a nitro derivative of aspirin. Proceedings of the National Academy of Sciences of the United States of America. 2006; 103:3914-9. [PubMed: 16497833]

224. Leonetti C, Scarsella M, Zupi G, Zoli W, Amadori D, Medri L, et al. Efficacy of a nitric oxidereleasing nonsteroidal anti-inflammatory drug and cytotoxic drugs in human colon cancer cell lines in vitro and xenografts. Molecular cancer therapeutics. 2006; 5:919-26. [PubMed: 16648562]

225. Zhao H, Ning S, Scicinski J, Oronsky B, Knox SJ, Peehl DM. Epigenetic effects of RRx-001: a possible unifying mechanism of anticancer activity. Oncotarget. 2015; 6:43172-81. [PubMed: 26657731]

226. Reid T, Oronsky B, Scicinski J, Scribner CL, Knox SJ, Ning S, et al. Safety and activity of RRx-001 in patients with advanced cancer: a first-in-human, open-label, dose-escalation phase 1 study. The Lancet Oncology. 2015; 16:1133-42. [PubMed: 26296952]

227. Brzezniak C, Oronsky B, Scicinski J, Caroen S, Cabrales P, Dean Abrouk N, et al. Conversion of Platinum-Etoposide-Resistant to Sensitive SCLC after Treatment with the Epi- 
Immunotherapeutic RRx-001: A Case Report. Oncology research and treatment. 2016; 39:720-3. [PubMed: 27855386]

228. Wallace JL, Ignarro LJ, Fiorucci S. Potential cardioprotective actions of no-releasing aspirin. Nature reviews Drug discovery. 2002; 1:375-82. [PubMed: 12120413]

229. Wallace JL, Soldato PD. The therapeutic potential of NO-NSAIDs. Fundam Clin Pharmacol. 2003; 17:11-20. [PubMed: 12588626]

230. Kashfi K. Anti-inflammatory agents as cancer therapeutics. Advances in pharmacology (San Diego, Calif). 2009; 57:31-89.

231. Kashfi K, Ryan Y, Qiao LL, Williams JL, Chen J, Del Soldato P, et al. Nitric oxide-donating nonsteroidal anti-inflammatory drugs inhibit the growth of various cultured human cancer cells: evidence of a tissue type-independent effect. The Journal of pharmacology and experimental therapeutics. 2002; 303:1273-82. [PubMed: 12438552]

232. Nath N, Liu X, Jacobs L, Kashfi K. Flurbiprofen benzyl nitrate (NBS-242) inhibits the growth of A-431 human epidermoid carcinoma cells and targets beta-catenin. Drug design, development and therapy. 2013; 7:389-96.

233. Kashfi K, Rigas B. Non-COX-2 targets and cancer: expanding the molecular target repertoire of chemoprevention. Biochem Pharmacol. 2005; 70:969-86. [PubMed: 15949789]

234. Dunlap T, Chandrasena RE, Wang Z, Sinha V, Wang Z, Thatcher GR. Quinone formation as a chemoprevention strategy for hybrid drugs: balancing cytotoxicity and cytoprotection. Chem Res Toxicol. 2007; 20:1903-12. [PubMed: 17975886]

235. Hulsman N, Medema JP, Bos C, Jongejan A, Leurs R, Smit MJ, et al. Chemical insights in the concept of hybrid drugs: the antitumor effect of nitric oxide-donating aspirin involves a quinone methide but not nitric oxide nor aspirin. J Med Chem. 2007; 50:2424-31. [PubMed: 17441704]

236. Kashfi K, Rigas B. The mechanism of action of nitric oxide-donating aspirin. Biochemical and biophysical research communications. 2007; 358:1096-101. [PubMed: 17512900]

237. Bak AW, McKnight W, Li P, Del Soldato P, Calignano A, Cirino G, et al. Cyclooxygenaseindependent chemoprevention with an aspirin derivative in a rat model of colonic adenocarcinoma. Life Sciences. 1998; 62:L367-73.

238. Williams JL, Kashfi K, Ouyang N, del Soldato P, Kopelovich L, Rigas B. NO-donating aspirin inhibits intestinal carcinogenesis in Min (APC(Min/+)) mice. Biochemical and biophysical research communications. 2004; 313:784-8. [PubMed: 14697260]

239. Rao CV, Reddy BS, Steele VE, Wang CX, Liu X, Ouyang N, et al. Nitric oxide-releasing aspirin and indomethacin are potent inhibitors against colon cancer in azoxymethane-treated rats: effects on molecular targets. Molecular cancer therapeutics. 2006; 5:1530-8. [PubMed: 16818512]

240. Ouyang N, Williams JL, Tsioulias GJ, Gao J, Iatropoulos MJ, Kopelovich L, et al. Nitric oxidedonating aspirin prevents pancreatic cancer in a hamster tumor model. Cancer research. 2006; 66:4503-11. [PubMed: 16618778]

241. Nicastro HL, Grubbs CJ, Margaret Juliana M, Bode AM, Kim MS, Lu Y, et al. Preventive effects of NSAIDs, NO-NSAIDs, and NSAIDs plus difluoromethylornithine in a chemically induced urinary bladder cancer model. Cancer prevention research (Philadelphia, Pa). 2014; 7:246-54.

242. Nath N, Chattopadhyay M, Rodes DB, Nazarenko A, Kodela R, Kashfi K. Nitric Oxide-Releasing Aspirin Suppresses NF-kappaB Signaling in Estrogen Receptor Negative Breast Cancer Cells in Vitro and in Vivo. Molecules (Basel, Switzerland). 2015; 20:12481-99.

243. Keefer LK. Fifty years of diazeniumdiolate research. From laboratory curiosity to broad-spectrum biomedical advances. ACS chemical biology. 2011; 6:1147-55. [PubMed: 21932836]

244. Nandurdikar RS, Maciag AE, Cao Z, Keefer LK, Saavedra JE. Diazeniumdiolated carbamates: a novel class of nitric oxide donors. Bioorganic \& medicinal chemistry. 2012; 20:2025-9. [PubMed: 22356735]

245. Paolocci N, Katori T, Champion HC, St John ME, Miranda KM, Fukuto JM, et al. Positive inotropic and lusitropic effects of $\mathrm{HNO} / \mathrm{NO}$ - in failing hearts: independence from beta-adrenergic signaling. Proceedings of the National Academy of Sciences of the United States of America. 2003; 100:5537-42. [PubMed: 12704230]

246. Paolocci N, Saavedra WF, Miranda KM, Martignani C, Isoda T, Hare JM, et al. Nitroxyl anion exerts redox-sensitive positive cardiac inotropy in vivo by calcitonin gene-related peptide 
signaling. Proceedings of the National Academy of Sciences of the United States of America. 2001; 98:10463-8. [PubMed: 11517312]

247. Nagasawa HT, Kawle SP, Elberling JA, DeMaster EG, Fukuto JM. Prodrugs of nitroxyl as potential aldehyde dehydrogenase inhibitors vis-a-vis vascular smooth muscle relaxants. J Med Chem. 1995; 38:1865-71. [PubMed: 7783118]

248. Norris AJ, Sartippour MR, Lu M, Park T, Rao JY, Jackson MI, et al. Nitroxyl inhibits breast tumor growth and angiogenesis. International journal of cancer. 2008; 122:1905-10. [PubMed: 18076071]

249. Basudhar D, Bharadwaj G, Cheng RY, Jain S, Shi S, Heinecke JL, et al. Synthesis and chemical and biological comparison of nitroxyl- and nitric oxide-releasing diazeniumdiolate-based aspirin derivatives. J Med Chem. 2013; 56:7804-20. [PubMed: 24102516]

250. Basudhar D, Cheng RC, Bharadwaj G, Ridnour LA, Wink DA, Miranda KM. Chemotherapeutic potential of diazeniumdiolate-based aspirin prodrugs in breast cancer. Free radical biology \& medicine. 2015; 83:101-14. [PubMed: 25659932]

251. Keefer LK. Broad-Spectrum Anti-Cancer Activity of O-Arylated Diazeniumdiolates. Forum on immunopathological diseases and therapeutics. 2010; 1:205-18. [PubMed: 21949595]

252. Shami PJ, Saavedra JE, Wang LY, Bonifant CL, Diwan BA, Singh SV, et al. JS-K, a glutathione/ glutathione S-transferase-activated nitric oxide donor of the diazeniumdiolate class with potent antineoplastic activity. Molecular cancer therapeutics. 2003; 2:409-17. [PubMed: 12700285]

253. Shami PJ, Maciag AE, Eddington JK, Udupi V, Kosak KM, Saavedra JE, et al. JS-K, an arylating nitric oxide (NO) donor, has synergistic anti-leukemic activity with cytarabine (ARA-C). Leuk Res. 2009; 33:1525-9. [PubMed: 19193435]

254. Findlay VJ, Townsend DM, Saavedra JE, Buzard GS, Citro ML, Keefer LK, et al. Tumor cell responses to a novel glutathione $\mathrm{S}$-transferase-activated nitric oxide-releasing prodrug. Molecular pharmacology. 2004; 65:1070-9. [PubMed: 15102935]

255. Saavedra JE, Srinivasan A, Buzard GS, Davies KM, Waterhouse DJ, Inami K, et al. PABA/NO as an anticancer lead: analogue synthesis, structure revision, solution chemistry, reactivity toward glutathione, and in vitro activity. J Med Chem. 2006; 49:1157-64. [PubMed: 16451080]

256. Kiziltepe T, Hideshima T, Ishitsuka K, Ocio EM, Raje N, Catley L, et al. JS-K, a GST-activated nitric oxide generator, induces DNA double-strand breaks, activates DNA damage response pathways, and induces apoptosis in vitro and in vivo in human multiple myeloma cells. Blood. 2007; 110:709-18. [PubMed: 17384201]

257. Shami PJ, Saavedra JE, Bonifant CL, Chu J, Udupi V, Malaviya S, et al. Antitumor activity of JS$\mathrm{K}$ [O2-(2,4-dinitrophenyl) 1-[(4-ethoxycarbonyl)piperazin-1-yl]diazen-1-ium-1,2-diolate] and related O2-aryl diazeniumdiolates in vitro and in vivo. J Med Chem. 2006; 49:4356-66. [PubMed: 16821795]

258. Chakrapani H, Goodblatt MM, Udupi V, Malaviya S, Shami PJ, Keefer LK, et al. Synthesis and in vitro anti-leukemic activity of structural analogues of JS-K, an anti-cancer lead compound. Bioorganic \& medicinal chemistry letters. 2008; 18:950-3. [PubMed: 18178089]

259. McMurtry V, Saavedra JE, Nieves-Alicea R, Simeone AM, Keefer LK, Tari AM. JS-K, a nitric oxide-releasing prodrug, induces breast cancer cell death while sparing normal mammary epithelial cells. International journal of oncology. 2011; 38:963-71. [PubMed: 21271218]

260. Maciag AE, Holland RJ, Robert Cheng YS, Rodriguez LG, Saavedra JE, Anderson LM, Keefer LK. Nitric oxide-releasing prodrug triggers cancer cell death through deregulation of cellular redox balance. Redox Biol. 2013 Feb 1.1:115-24. [PubMed: 24024144]

261. Nath N, Chattopadhyay M, Pospishil L, Cieciura LZ, Goswami S, Kodela R, et al. JS-K, a nitric oxide-releasing prodrug, modulates $\beta$-catenin/TCF signaling in leukemic Jurkat cells: evidence of an S-nitrosylated mechanism. Biochem Pharmacol. 2010; 80:1641-9. [PubMed: 20797387]

262. Chattopadhyay M, Kodela R, Olson KR, Kashfi K. NOSH-aspirin (NBS-1120), a novel nitric oxide- and hydrogen sulfide-releasing hybrid is a potent inhibitor of colon cancer cell growth in vitro and in a xenograft mouse model. Biochemical and biophysical research communications. 2012; 419:523-8. [PubMed: 22366248] 
263. Sikder N, Sikder AK, Bulakh NR, Gandhe BR. 1,3,3-Trinitroazetidine (TNAZ), a melt-cast explosive: synthesis, characterization and thermal behaviour. Journal of hazardous materials. 2004; 113:35-43. [PubMed: 15363512]

264. Knox, SJ., Cannizzo, L., Warner, K., Wardle, R., Velarde, S., Ning, S. Cyclic nitro compounds, pharmaceutical compositions thereof and uses thereof. United States: RadioRx, Inc., Alliant Techsystems Inc; 2009.

265. Vitturi DA, Sun CW, Harper VM, Thrash-Williams B, Cantu-Medellin N, Chacko BK, et al. Antioxidant functions for the hemoglobin beta93 cysteine residue in erythrocytes and in the vascular compartment in vivo. Free radical biology \& medicine. 2013; 55:119-29. [PubMed: 23159546]

266. Scicinski J, Oronsky B, Cooper V, Taylor M, Alexander M, Hadar R, et al. Development of methods for the bioanalysis of RRx-001 and metabolites. Bioanalysis. 2014; 6:947-56. [PubMed: 24806903]

267. Scicinski J, Oronsky B, Taylor M, Luo G, Musick T, Marini J, et al. Preclinical evaluation of the metabolism and disposition of RRx-001, a novel investigative anticancer agent. Drug metabolism and disposition: the biological fate of chemicals. 2012; 40:1810-6. [PubMed: 22699395]

268. Ning S, Sekar TV, Scicinski J, Oronsky B, Peehl DM, Knox SJ, et al. Nrf2 activity as a potential biomarker for the pan-epigenetic anticancer agent, RRx-001. Oncotarget. 2015; 6:21547-56. [PubMed: 26280276]

269. Scicinski J, Oronsky B, Ning S, Knox S, Peehl D, Kim MM, et al. NO to cancer: The complex and multifaceted role of nitric oxide and the epigenetic nitric oxide donor, RRx-001. Redox biology. 2015; 6:1-8. [PubMed: 26164533]

270. Ning S, Bednarski M, Oronsky B, Scicinski J, Saul G, Knox SJ. Dinitroazetidines are a novel class of anticancer agents and hypoxia-activated radiation sensitizers developed from highly energetic materials. Cancer research. 2012; 72:2600-8. [PubMed: 22589277]

271. Daff S. NO synthase: structures and mechanisms. Nitric oxide : biology and chemistry / official journal of the Nitric Oxide Society. 2010; 23:1-11.

272. Crane BR, Arvai AS, Gachhui R, Wu C, Ghosh DK, Getzoff ED, et al. The structure of nitric oxide synthase oxygenase domain and inhibitor complexes. Science (New York, NY). 1997; 278:425-31.

273. Fischmann TO, Hruza A, Niu XD, Fossetta JD, Lunn CA, Dolphin E, et al. Structural characterization of nitric oxide synthase isoforms reveals striking active-site conservation. Nature structural biology. 1999; 6:233-42. [PubMed: 10074942]

274. Raman CS, Li H, Martasek P, Kral V, Masters BS, Poulos TL. Crystal structure of constitutive endothelial nitric oxide synthase: a paradigm for pterin function involving a novel metal center. Cell. 1998; 95:939-50. [PubMed: 9875848]

275. Li H, Shimizu H, Flinspach M, Jamal J, Yang W, Xian M, et al. The novel binding mode of Nalkyl-N'-hydroxyguanidine to neuronal nitric oxide synthase provides mechanistic insights into NO biosynthesis. Biochemistry. 2002; 41:13868-75. [PubMed: 12437343]

276. Ji H, Stanton BZ, Igarashi J, Li H, Martasek P, Roman LJ, et al. Minimal pharmacophoric elements and fragment hopping, an approach directed at molecular diversity and isozyme selectivity. Design of selective neuronal nitric oxide synthase inhibitors. Journal of the American Chemical Society. 2008; 130:3900-14. [PubMed: 18321097]

277. Vitecek J, Lojek A, Valacchi G, Kubala L. Arginine-based inhibitors of nitric oxide synthase: therapeutic potential and challenges. Mediators of inflammation. 2012; 2012:318087. [PubMed: 22988346]

278. Mukherjee P, Cinelli MA, Kang S, Silverman RB. Development of nitric oxide synthase inhibitors for neurodegeneration and neuropathic pain. Chemical Society reviews. 2014; 43:6814-38. [PubMed: 24549364]

279. Cheng, R., Ridnour, LA., Glynn, SA., Switzer, CH., Flores-Santana, W., Hussain, P., et al. Nitric Oxide and Cancer: An Overview. In: Bonavida, B., editor. Nitric Oxide (NO) and Cancer: Prognosis, Prevention, and Therapy. Springer; 2010. p. 3-20. 
280. Saied EM, El-Etreby NM. The role and prognostic value of inducible nitric oxide synthase (iNOS) and interleukin-33 (IL-33) in serous and mucinous epithelial ovarian tumours. Annals of diagnostic pathology. 2017; 27:62-8. [PubMed: 28325363]

281. de Oliveira GA, Cheng RYS, Ridnour LA, Basudhar D, Somasundaram V, McVicar DW, et al. Inducible Nitric Oxide Synthase in the Carcinogenesis of Gastrointestinal Cancers. Antioxidants \& redox signaling. 2017; 26:1059-77. [PubMed: 27494631]

282. Switzer CH, Glynn SA, Ridnour LA, Cheng RY, Vitek MP, Ambs S, et al. Nitric oxide and protein phosphatase 2A provide novel therapeutic opportunities in ER-negative breast cancer. Trends Pharmacol Sci. 2011; 32:644-51. [PubMed: 21893353]

283. Anttila MA, Voutilainen K, Merivalo S, Saarikoski S, Kosma VM. Prognostic significance of iNOS in epithelial ovarian cancer. Gynecologic oncology. 2007; 105:97-103. [PubMed: 17174383]

284. Puhakka A, Kinnula V, Napankangas U, Saily M, Koistinen P, Paakko P, et al. High expression of nitric oxide synthases is a favorable prognostic sign in non-small cell lung carcinoma. APMIS : acta pathologica, microbiologica, et immunologica Scandinavica. 2003; 111:1137-46.

285. Alderton WK, Angell AD, Craig C, Dawson J, Garvey E, Moncada S, et al. GW274150 and GW273629 are potent and highly selective inhibitors of inducible nitric oxide synthase in vitro and in vivo. British journal of pharmacology. 2005; 145:301-12. [PubMed: 15778742]

286. Kostourou V, Cartwright JE, Johnstone AP, Boult JK, Cullis ER, Whitley G, et al. The role of tumour-derived iNOS in tumour progression and angiogenesis. British journal of cancer. 2011; 104:83-90. [PubMed: 21139581]

287. Sikora AG, Gelbard A, Davies MA, Sano D, Ekmekcioglu S, Kwon J, et al. Targeted inhibition of inducible nitric oxide synthase inhibits growth of human melanoma in vivo and synergizes with chemotherapy. Clinical cancer research : an official journal of the American Association for Cancer Research. 2010; 16:1834-44. [PubMed: 20215556]

288. Lee M, Tazzari V, Giustarini D, Rossi R, Sparatore A, Del Soldato P, et al. Effects of hydrogen sulfide-releasing L-DOPA derivatives on glial activation: potential for treating Parkinson disease. The Journal of biological chemistry. 2010; 285:17318-28. [PubMed: 20368333]

289. Whiteman M, Perry A, Zhou Z, Bucci M, Papapetropoulos A, Cirino G, et al. Phosphinodithioate and Phosphoramidodithioate Hydrogen Sulfide Donors. Handbook of experimental pharmacology. 2015; 230:337-63. [PubMed: 26162843]

290. Shukla N, Rossoni G, Hotston M, Sparatore A, Del Soldato P, Tazzari V, et al. Effect of hydrogen sulphide-donating sildenafil (ACS6) on erectile function and oxidative stress in rabbit isolated corpus cavernosum and in hypertensive rats. BJU Int. 2009; 103:1522-9. [PubMed: 19245441]

291. Lee M, Sparatore A, Del Soldato P, McGeer E, McGeer PL. Hydrogen sulfide-releasing NSAIDs attenuate neuroinflammation induced by microglial and astrocytic activation. Glia. 2010; 58:10313. [PubMed: 19544392]

292. Perrino E, Uliva C, Lanzi C, Soldato PD, Masini E, Sparatore A. New prostaglandin derivative for glaucoma treatment. Bioorganic \& medicinal chemistry letters. 2009; 19:1639-42. [PubMed: 19233645]

293. Sparatore A, Santus G, Giustarini D, Rossi R, Del Soldato P. Therapeutic potential of new hydrogen sulfide-releasing hybrids. Expert Rev Clin Pharmacol. 2011; 4:109-21. [PubMed: 22115352]

294. Zhang J, Xie Y, Xu Y, Pan Y, Shao C. Hydrogen sulfide contributes to hypoxia-induced radioresistance on hepatoma cells. Journal of radiation research. 2011; 52:622-8. [PubMed: 21952317]

295. Asimakopoulou A, Panopoulos P, Chasapis CT, Coletta C, Zhou Z, Cirino G, et al. Selectivity of commonly used pharmacological inhibitors for cystathionine beta synthase (CBS) and cystathionine gamma lyase (CSE). British journal of pharmacology. 2013; 169:922-32. [PubMed: 23488457]

296. De Preter G, Deriemaeker C, Danhier P, Brisson L, Cao Pham TT, Gregoire V, et al. A Fast Hydrogen Sulfide-Releasing Donor Increases the Tumor Response to Radiotherapy. Molecular cancer therapeutics. 2016; 15:154-61. [PubMed: 26682572] 
297. Della Coletta Francescato H, Cunha FQ, Costa RS, Barbosa Junior F, Boim MA, Arnoni CP, et al. Inhibition of hydrogen sulphide formation reduces cisplatin-induced renal damage. Nephrology, dialysis, transplantation : official publication of the European Dialysis and Transplant Association - European Renal Association. 2011; 26:479-88.

298. Ahangarpour A, Abdollahzade Fard A, Gharibnaseri MK, Jalali T, Rashidi I. Hydrogen sulfide ameliorates the kidney dysfunction and damage in cisplatin-induced nephrotoxicity in rat. Veterinary research forum : an international quarterly journal. 2014; 5:121-7. [PubMed: 25568705]

299. Liu M, Jia Z, Sun Y, Zhang A, Yang T. A H 2 S Donor GYY4137 Exacerbates Cisplatin-Induced Nephrotoxicity in Mice. Mediators of inflammation. 2016; 2016:8145785. [PubMed: 27340345]

300. Li L, Whiteman M, Guan YY, Neo KL, Cheng Y, Lee SW, et al. Characterization of a novel, water-soluble hydrogen sulfide-releasing molecule (GYY4137): new insights into the biology of hydrogen sulfide. Circulation. 2008; 117:2351-60. [PubMed: 18443240]

301. Lee ZW, Zhou J, Chen CS, Zhao Y, Tan CH, Li L, et al. The slow-releasing hydrogen sulfide donor, GYY4137, exhibits novel anti-cancer effects in vitro and in vivo. PloS one. 2011; 6:e21077. [PubMed: 21701688]

302. Lu S, Gao Y, Huang X, Wang X. GYY4137, a hydrogen sulfide (H(2)S) donor, shows potent antihepatocellular carcinoma activity through blocking the STAT3 pathway. International journal of oncology. 2014; 44:1259-67. [PubMed: 24535538]

303. Lee ZW, Teo XY, Tay EY, Tan CH, Hagen T, Moore PK, et al. Utilizing hydrogen sulfide as a novel anti-cancer agent by targeting cancer glycolysis and $\mathrm{pH}$ imbalance. British journal of pharmacology. 2014; 171:4322-36. [PubMed: 24827113]

304. Putz VR, Johnson BL, Setzer JV. A comparative study of the effects of carbon monoxide and methylene chloride on human performance. Journal of environmental pathology and toxicology. 1979; 2:97-112. [PubMed: 512567]

305. Fagin J, Bradley J, Williams D. Carbon monoxide poisoning secondary to inhaling methylene chloride. British medical journal. 1980; 281:1461.

306. Peers C, Boyle JP, Scragg JL, Dallas ML, Al-Owais MM, Hettiarachichi NT, et al. Diverse mechanisms underlying the regulation of ion channels by carbon monoxide. British journal of pharmacology. 2015; 172:1546-56. [PubMed: 24818840]

307. Peers C, Lefer DJ. Emerging roles for gasotransmitters. Experimental physiology. 2011; 96:8312. [PubMed: 21865534]

308. Nassour I, Kautza B, Rubin M, Escobar D, Luciano J, Loughran P, et al. Carbon monoxide protects against hemorrhagic shock and resuscitation-induced microcirculatory injury and tissue injury. Shock (Augusta, Ga). 2015; 43:166-71.

309. Kashfi K. Anti-cancer activity of new designer hydrogen sulfide-donating hybrids. Antioxidants \& redox signaling. 2014; 20:831-46. [PubMed: 23581880]

310. Chattopadhyay M, Kodela R, Nath N, Barsegian A, Boring D, Kashfi K. Hydrogen sulfidereleasing aspirin suppresses NF-kappaB signaling in estrogen receptor negative breast cancer cells in vitro and in vivo. Biochem Pharmacol. 2012; 83:723-32. [PubMed: 22209867]

311. Chattopadhyay M, Kodela R, Nath N, Dastagirzada YM, Velazquez-Martinez CA, Boring D, et al. Hydrogen sulfide-releasing NSAIDs inhibit the growth of human cancer cells: a general property and evidence of a tissue type-independent effect. Biochem Pharmacol. 2012; 83:715-22. [PubMed: 22222427]

312. Chattopadhyay M, Kodela R, Nath N, Street CR, Velazquez-Martinez CA, Boring D, et al. Hydrogen sulfide-releasing aspirin modulates xenobiotic metabolizing enzymes in vitro and in vivo. Biochem Pharmacol. 2012; 83:733-40. [PubMed: 22209714]

313. Elsheikh W, Blackler RW, Flannigan KL, Wallace JL. Enhanced chemopreventive effects of a hydrogen sulfide-releasing anti-inflammatory drug (ATB-346) in experimental colorectal cancer. Nitric oxide : biology and chemistry / official journal of the Nitric Oxide Society. 2014; 41:1317.

314. De Cicco P, Panza E, Ercolano G, Armogida C, Sessa G, Pirozzi G, et al. ATB-346, a novel hydrogen sulfide-releasing anti-inflammatory drug, induces apoptosis of human melanoma cells 
and inhibits melanoma development in vivo. Pharmacological research. 2016; 114:67-73.

[PubMed: 27777130]

315. Paul-Clark M, Elsheikh W, Kirkby N, Chan M, Devchand P, Agbor TA, et al. Profound Chemopreventative Effects of a Hydrogen Sulfide-Releasing NSAID in the APCMin/+ Mouse Model of Intestinal Tumorigenesis. PloS one. 2016; 11:e0147289. [PubMed: 26910063]

316. Ekundi-Valentim E, Mesquita FP, Santos KT, de Paula MA, Florenzano J, Zanoni CI, et al. A comparative study on the anti-inflammatory effects of single oral doses of naproxen and its hydrogen sulfide (H2S)-releasing derivative ATB-346 in rats with carrageenan-induced synovitis. Medical gas research. 2013; 3:24. [PubMed: 24237604]

317. Li M, Li J, Zhang T, Zhao Q, Cheng J, Liu B, et al. Syntheses, toxicities and anti- inflammation of H2S-donors based on non-steroidal anti-inflammatory drugs. European journal of medicinal chemistry. 2017; 138:51-65. [PubMed: 28646655]

318. Kodela R, Chattopadhyay M, Kashfi K. Synthesis and biological activity of NOSH- naproxen (AVT-219) and NOSH-sulindac (AVT-18A) as potent anti-inflammatory agents with chemotherapeutic potential. MedChemComm. 2013:4.

319. Li L, Salto-Tellez M, Tan CH, Whiteman M, Moore PK. GYY4137, a novel hydrogen sulfidereleasing molecule, protects against endotoxic shock in the rat. Free radical biology \& medicine. 2009; 47:103-13. [PubMed: 19375498]

320. Li L, Rossoni G, Sparatore A, Lee LC, Del Soldato P, Moore PK. Anti-inflammatory and gastrointestinal effects of a novel diclofenac derivative. Free radical biology \& medicine. 2007; 42:706-19. [PubMed: 17291994]

321. Switzer CH, Cheng RY, Ridnour LA, Murray MC, Tazzari V, Sparatore A, et al. Dithiolethiones inhibit NF-kappaB activity via covalent modification in human estrogen receptor-negative breast cancer. Cancer research. 2012; 72:2394-404. [PubMed: 22436383]

322. Kodela R, Nath N, Chattopadhyay M, Nesbitt DE, Velazquez-Martinez CA, Kashfi K. Hydrogen sulfide-releasing naproxen suppresses colon cancer cell growth and inhibits NF-kappaB signaling. Drug design, development and therapy. 2015; 9:4873-82.

323. Gan, Z., Chattopadhyay, M., Kodela, R., Boring, D., Crowell, J., Kashfi, K. Hydrogen sulfidereleasing aspirin inhibits the growth of leukemic Jurkat cells and modulates $\beta$-catenin expression. American Association for Cancer Research, 102nd Annual Meeting; April 2-6; Orlando FL. 2011.

324. Kodela R, Chattopadhyay M, Kashfi K. NOSH-Aspirin: A Novel Nitric Oxide-Hydrogen SulfideReleasing Hybrid: A New Class of Anti-inflammatory Pharmaceuticals. ACS Med Chem Lett. 2012; 3:257-62. [PubMed: 22916316]

325. Kodela R, Chattopadhyay M, Velazquez-Martinez CA, Kashfi K. NOSH-aspirin (NBS-1120), a novel nitric oxide- and hydrogen sulfide-releasing hybrid has enhanced chemo-preventive properties compared to aspirin, is gastrointestinal safe with all the classic therapeutic indications. Biochem Pharmacol. 2015; 98:564-72. [PubMed: 26394025]

326. Chattopadhyay M, Kodela R, Duvalsaint PL, Kashfi K. Gastrointestinal safety, chemotherapeutic potential, and classic pharmacological profile of NOSH-naproxen (AVT-219) a dual NO- and H2S-releasing hybrid. Pharmacology research \& perspectives. 2016; 4:e00224. [PubMed: 27069635]

327. Kashfi K, Chattopadhyay M, Kodela R. NOSH-sulindac (AVT-18A) is a novel nitric oxide- and hydrogen sulfide-releasing hybrid that is gastrointestinal safe and has potent anti-inflammatory, analgesic, antipyretic, anti-platelet, and anti-cancer properties. Redox biology. 2015; 6:287-96. [PubMed: 26298203]

328. Fonseca MD, Cunha FQ, Kashfi K, Cunha TM. NOSH-aspirin (NBS-1120), a dual nitric oxide and hydrogen sulfide-releasing hybrid, reduces inflammatory pain. Pharmacology research \& perspectives. 2015; 3:e00133. [PubMed: 26236481]

329. Chattopadhyay M, Velazquez CA, Pruski A, Nia KV, Abdellatif KR, Keefer LK, et al. Comparison between 3-Nitrooxyphenyl acetylsalicylate (NO-ASA) and O2(acetylsalicyloxymethyl)-1-(pyrrolidin-1-yl)diazen-1-ium-1,2-diolate (NONO-ASA) as safe antiinflammatory, analgesic, antipyretic, antioxidant prodrugs. The Journal of pharmacology and experimental therapeutics. 2010; 335:443-50. [PubMed: 20679133] 
330. Szabo C, Papapetropoulos A. Hydrogen sulphide and angiogenesis: mechanisms and applications. British journal of pharmacology. 2011; 164:853-65. [PubMed: 21198548]

331. Whiteman M, Le Trionnaire S, Chopra M, Fox B, Whatmore J. Emerging role of hydrogen sulfide in health and disease: critical appraisal of biomarkers and pharmacological tools. Clinical science (London, England : 1979). 2011; 121:459-88.

332. Szczesny B, Modis K, Yanagi K, Coletta C, Le Trionnaire S, Perry A, et al. AP39, a novel mitochondria-targeted hydrogen sulfide donor, stimulates cellular bioenergetics, exerts cytoprotective effects and protects against the loss of mitochondrial DNA integrity in oxidatively stressed endothelial cells in vitro. Nitric oxide : biology and chemistry / official journal of the Nitric Oxide Society. 2014; 41:120-30.

333. Distrutti E, Sediari L, Mencarelli A, Renga B, Orlandi S, Antonelli E, et al. Evidence that hydrogen sulfide exerts antinociceptive effects in the gastrointestinal tract by activating KATP channels. The Journal of pharmacology and experimental therapeutics. 2006; 316:325-35. [PubMed: 16192316]

334. Distrutti E, Sediari L, Mencarelli A, Renga B, Orlandi S, Russo G, et al. 5-Amino-2hydroxybenzoic acid 4-(5-thioxo-5H [1,2]dithiol-3yl)-phenyl ester (ATB-429), a hydrogen sulfide-releasing derivative of mesalamine, exerts antinociceptive effects in a model of postinflammatory hypersensitivity. The Journal of pharmacology and experimental therapeutics. 2006; 319:447-58. [PubMed: 16855178]

335. Ekundi-Valentim E, Santos KT, Camargo EA, Denadai-Souza A, Teixeira SA, Zanoni CI, et al. Differing effects of exogenous and endogenous hydrogen sulphide in carrageenan-induced knee joint synovitis in the rat. British journal of pharmacology. 2010; 159:1463-74. [PubMed: 20136840]

336. Chan MV, Wallace JL. Hydrogen sulfide-based therapeutics and gastrointestinal diseases: translating physiology to treatments. American journal of physiology Gastrointestinal and liver physiology. 2013; 305:G467-73. [PubMed: 23868410]

337. Fiorucci S, Orlandi S, Mencarelli A, Caliendo G, Santagada V, Distrutti E, et al. Enhanced activity of a hydrogen sulphide-releasing derivative of mesalamine (ATB-429) in a mouse model of colitis. British journal of pharmacology. 2007; 150:996-1002. [PubMed: 17339831]

338. You J, Shi X, Liang H, Ye J, Wang L, Han H, et al. Cystathionine- gamma-lyase promotes process of breast cancer in association with STAT3 signaling pathway. Oncotarget. 2017; 8:65677-86. [PubMed: 29029463]

339. Bronowicka-Adamska P, Bentke A, Wrobel M. Hydrogen sulfide generation from l-cysteine in the human glioblastoma-astrocytoma U-87 MG and neuroblastoma SHSY5Y cell lines. Acta biochimica Polonica. 2017; 64:171-6. [PubMed: 28291844]

340. Fan K, Li N, Qi J, Yin P, Zhao C, Wang L, et al. Wnt/beta-catenin signaling induces the transcription of cystathionine-gamma-lyase, a stimulator of tumor in colon cancer. Cellular signalling. 2014; 26:2801-8. [PubMed: 25193114]

341. Takano N, Sarfraz Y, Gilkes DM, Chaturvedi P, Xiang L, Suematsu M, et al. Decreased expression of cystathionine beta-synthase promotes glioma tumorigenesis. Molecular cancer research : MCR. 2014; 12:1398-406. [PubMed: 24994751]

342. Ma Q, Hoper M, Anderson N, Rowlands BJ. Effect of supplemental L-arginine in a chemicalinduced model of colorectal cancer. World journal of surgery. 1996; 20:1087-91. [PubMed: 8798369]

343. Yeh CL, Pai MH, Li CC, Tsai YL, Yeh SL. Effect of arginine on angiogenesis induced by human colon cancer: in vitro and in vivo studies. The Journal of nutritional biochemistry. 2010; 21:53843. [PubMed: 19447018]

344. Ma Q, Wang Y, Gao X, Ma Z, Song Z. L-arginine reduces cell proliferation and ornithine decarboxylase activity in patients with colorectal adenoma and adenocarcinoma. Clinical cancer research : an official journal of the American Association for Cancer Research. 2007; 13:740712. [PubMed: 18094424]

345. Adams C, McCarthy HO, Coulter JA, Worthington J, Murphy C, Robson T, et al. Nitric oxide synthase gene therapy enhances the toxicity of cisplatin in cancer cells. The journal of gene medicine. 2009; 11:160-8. [PubMed: 19062185] 
346. Chung P, Cook T, Liu K, Vodovotz Y, Zamora R, Finkelstein S, et al. Overexpression of the human inducible nitric oxide synthase gene enhances radiation-induced apoptosis in colorectal cancer cells via a caspase-dependent mechanism. Nitric oxide : biology and chemistry / official journal of the Nitric Oxide Society. 2003; 8:119-26.

347. Soler MN, Bobe P, Benihoud K, Lemaire G, Roos BA, Lausson S. Gene therapy of rat medullary thyroid cancer by naked nitric oxide synthase II DNA injection. The journal of gene medicine. 2000; 2:344-52. [PubMed: 11045428]

348. Le X, Wei D, Huang S, Lancaster JR Jr, Xie K. Nitric oxide synthase II suppresses the growth and metastasis of human cancer regardless of its up-regulation of protumor factors. Proceedings of the National Academy of Sciences of the United States of America. 2005; 102:8758-63. [PubMed: 15939886]

349. Juang SH, Xie K, Xu L, Wang Y, Yoneda J, Fidler IJ. Use of retroviral vectors encoding murine inducible nitric oxide synthase gene to suppress tumorigenicity and cancer metastasis of murine melanoma. Cancer biotherapy \& radiopharmaceuticals. 1997; 12:167-75. [PubMed: 10851463]

350. Fiorucci S, Santucci L, Gresele P, Faccino RM, Del Soldato P, Morelli A. Gastrointestinal safety of NO-aspirin (NCX-4016) in healthy human volunteers: a proof of concept endoscopic study. Gastroenterology. 2003; 124:600-7. [PubMed: 12612897]

351. Fiorucci S, Santucci L, Wallace JL, Sardina M, Romano M, del Soldato P, et al. Interaction of a selective cyclooxygenase-2 inhibitor with aspirin and NO-releasing aspirin in the human gastric mucosa. Proceedings of the National Academy of Sciences of the United States of America. 2003; 100:10937-41. [PubMed: 12960371]

352. Fiorucci S, Mencarelli A, Meneguzzi A, Lechi A, Renga B, del Soldato P, et al. Co-administration of nitric oxide-aspirin (NCX-4016) and aspirin prevents platelet and monocyte activation and protects against gastric damage induced by aspirin in humans. Journal of the American College of Cardiology. 2004; 44:635-41. [PubMed: 15358033]

353. NicOx SA. NicOx provides an update on NCX-4016. Sophia Antipolis; France: 2007. http:// www.nicox.com/wp-content/uploads/pr2007061800en.pdf?4051a2

354. Schnitzer TJ, Hochberg MC, Marrero CE, Duquesroix B, Frayssinet H, Beekman M. Efficacy and safety of naproxcinod in patients with osteoarthritis of the knee: a 53-week prospective randomized multicenter study. Seminars in arthritis and rheumatism. 2011; 40:285-97. [PubMed: 20828790]

355. Schnitzer TJ, Kivitz A, Frayssinet H, Duquesroix B. Efficacy and safety of naproxcinod in the treatment of patients with osteoarthritis of the knee: a 13-week prospective, randomized, multicenter study. Osteoarthritis and cartilage / OARS, Osteoarthritis Research Society. 2010; 18:629-39.

356. Karlsson J, Pivodic A, Aguirre D, Schnitzer TJ. Efficacy, safety, and tolerability of the cyclooxygenase-inhibiting nitric oxide donator naproxcinod in treating osteoarthritis of the hip or knee. The Journal of rheumatology. 2009; 36:1290-7. [PubMed: 19411388]

357. Schnitzer TJ, Kivitz AJ, Lipetz RS, Sanders N, Hee A. Comparison of the COX-inhibiting nitric oxide donator AZD3582 and rofecoxib in treating the signs and symptoms of Osteoarthritis of the knee. Arthritis and rheumatism. 2005; 53:827-37. [PubMed: 16342089]

358. Lohmander LS, McKeith D, Svensson O, Malmenas M, Bolin L, Kalla A, et al. A randomised, placebo controlled, comparative trial of the gastrointestinal safety and efficacy of AZD3582 versus naproxen in osteoarthritis. Annals of the rheumatic diseases. 2005; 64:449-56. [PubMed: 15345500]

359. NicOx SA. FDA provides Complete Response Letter to NicOx's New Drug Application for naproxcinod. 2010. http://www.nicox.com/wp-content/uploads/pr2010072200en.pdf?aeb643

360. Rigas B, Kashfi K. Cancer prevention: a new era beyond cyclooxygenase-2. The Journal of pharmacology and experimental therapeutics. 2005; 314:1-8. [PubMed: 15805430] 


\section{A. NO Biosynthesis}

L-Arginine

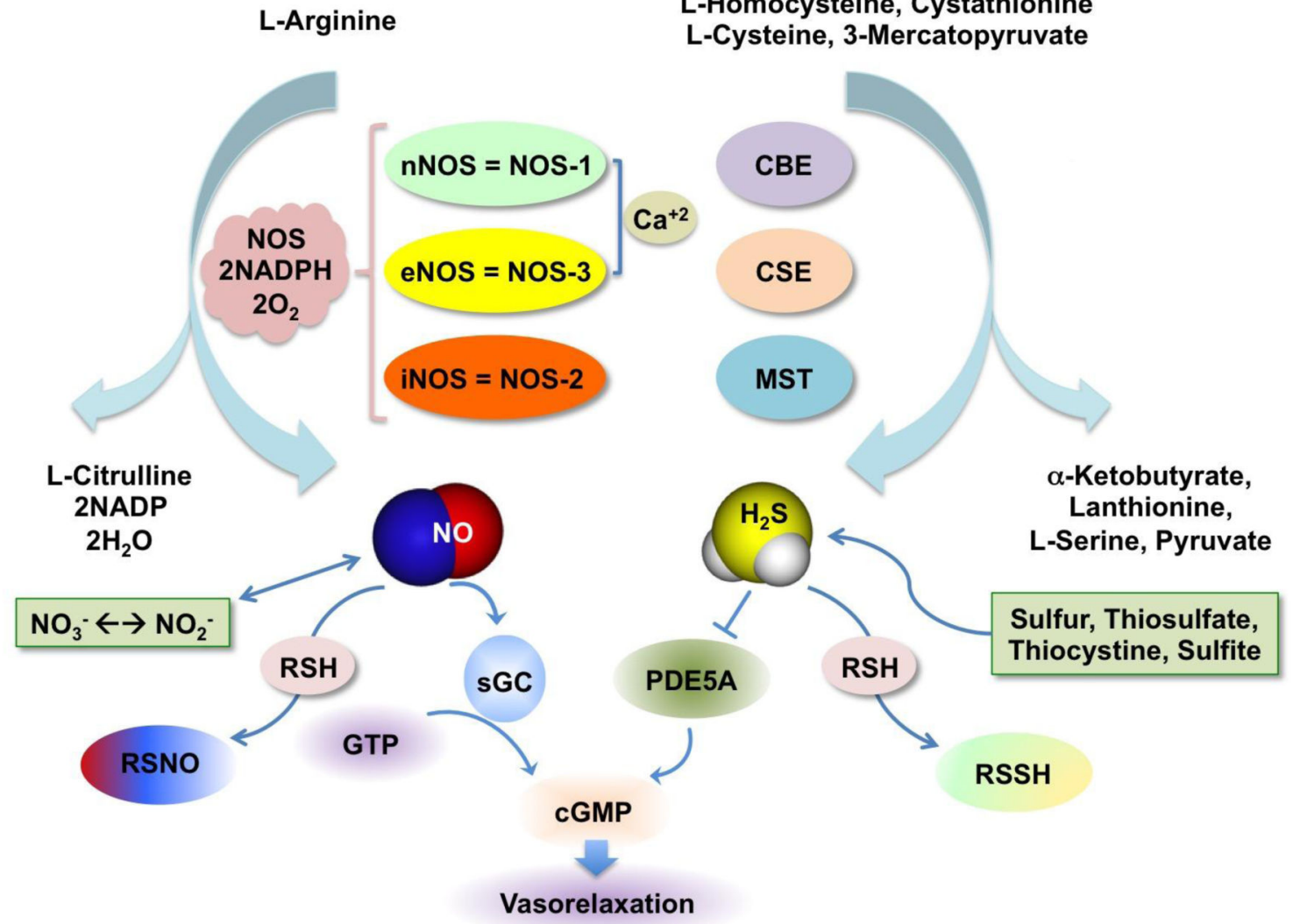

Figure 1.

Biosynthesis of nitric oxide and hydrogen sulfide. NO is produced by three nitric oxide synthase (NOS) isoforms: neuronal, endothelial, and inducible (nNOS, eNOS, and iNOS) that catalyze the oxidation of L-arginine to L-citrulline. NO is also produced through reduction of nitrite/nitrate under low oxygen conditions. $\mathrm{H}_{2} \mathrm{~S}$ is generated from oxidation of the substrates L- homocysteine, cystathionine, L-cysteine and 3-mercaptopyruvate through the enzymes cystathionine $\beta$-synthase (CBS) and cystathionine $\gamma$-lyase (CSE) and 3mercaptopyruvate sulfurtransferase (3-MST). a-ketobutyrate, lanthionine, L-serine and pyruvate are the secondary products formed. Alternatively, production of $\mathrm{H}_{2} \mathrm{~S}$ occurs nonenzymatically from various storage forms of sulfur like thiosulfate, thiocysteine and sulfite. NO reacts with the active site of soluble guanylate cyclase (sGC) and produces cyclic GMP leading to vasorelaxation. Whereas $\mathrm{H}_{2} \mathrm{~S}$ raises cGMP levels through inhibition of phosphodiesterase 5A (PDE5A) an enzyme that catabolizes it. NO can affect cellular proteins by producing peroxynitrite which in turn can interact with cysteine residues to form S-nitrosothiols (RSNO). $\mathrm{H}_{2} \mathrm{~S}$ can also interact with sulfhydryl group of cysteines and proteins to form persulfides (R-SSH). 


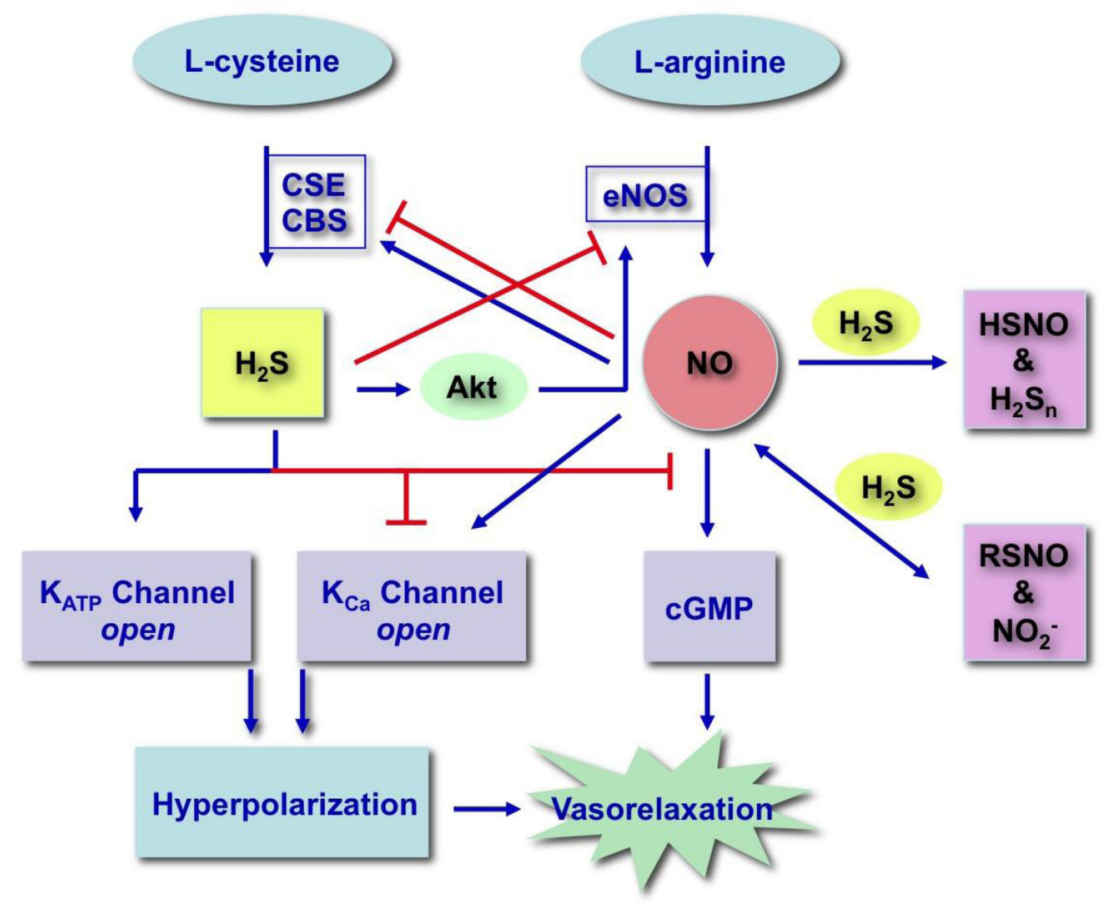

Figure 2.

NO- $\mathrm{H}_{2} \mathrm{~S}$ cross-talk in the vascular tissue. $\mathrm{H}_{2} \mathrm{~S}$ decreases the expression level of NO-synthase (eNOS) in a cell-free system [128], while NO can either inhibit CBS activity in a cell free system [127] or increases the expression levels of CSE and CBS [11] to increase $\mathrm{H}_{2} \mathrm{~S}$ synthesis. $\mathrm{H}_{2} \mathrm{~S}$ activates eNOS by an Akt-dependent phosphorylation of the protein [132]. NO can interact with $\mathrm{H}_{2} \mathrm{~S}$ to form $\mathrm{HSNO}$ [138] and $\mathrm{H}_{2} \mathrm{~S}_{\mathrm{n}}$ [139]; $\mathrm{H}_{2} \mathrm{~S}$ can interact with $\mathrm{NO}_{2}{ }^{-}$ [124] or with RSNO [147, 148] to produce NO. $\mathrm{H}_{2} \mathrm{~S}$ decreases the sensitivity of the cGMP pathways and also it modifies $\mathrm{K}_{\mathrm{Ca}}$ channels to decrease their sensitivity to NO. Solid arrows (blue) indicate stimulatory, while T-shaped arrows (red) indicate inhibitory inputs. 
(A) $\mathrm{R}-\mathrm{X}-\mathrm{ONO}_{2}$

$\mathrm{R}=$ Traditional NSAID

$\mathrm{X}=$ spacer, either aromatic or aliphatic

$\mathrm{ONO}_{2}=\mathrm{NO}$ releasing moiety
(C)

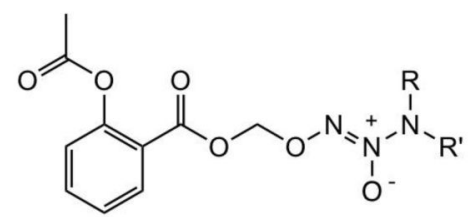

$\mathrm{R}=$ isopropyl, $\mathrm{R}^{\prime}=\mathrm{H}$; IPA/NO-aspirin

$\mathrm{R}=\mathrm{R}^{\prime}=$ ethyl; DEA/NO-aspirin

(B)

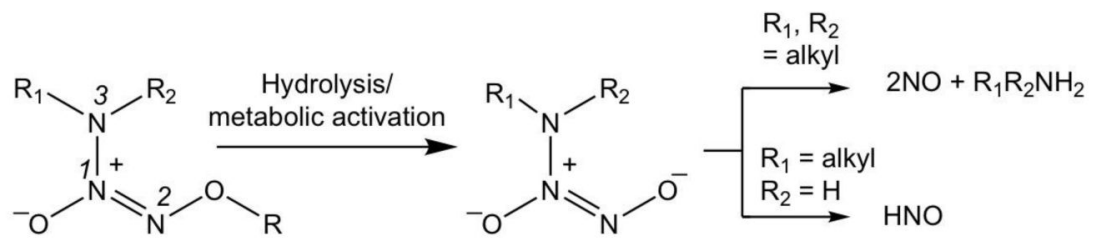

(D)

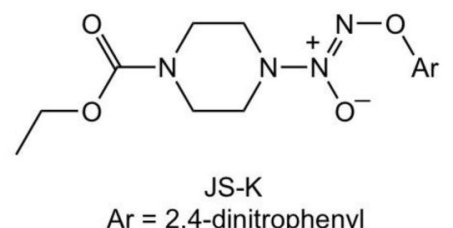

$(\mathrm{E})$<smiles>CCCCON(C)OCCCCCCOC(=O)c1ccc(NC)cc1</smiles>

(F)<smiles>O=C(CBr)N1CC([N+](=O)[O-])([N+](=O)[O-])C1</smiles>

Figure 3.

Chemical structures of selected NO-donating compounds. (A) NO-NSAIDs. (B) Activation of diazeniumdiolate prodrugs to release NO or HNO. (C) Structures of IPA/NO-aspirin and DEA/NO-aspirin. (D) JS-K; (E) PABA/NO and (F) RRx-001. 
A<smiles>COc1ccc(P(N)(=S)S)cc1</smiles><smiles>C1C2CC1O2</smiles>

C Traditional $\mathrm{H}_{2} \mathrm{~S}$ releasing NSAID

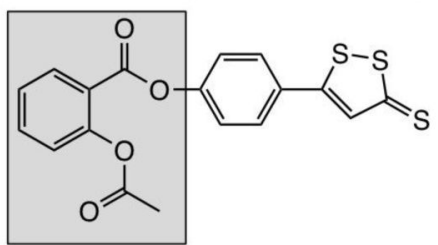

Aspirin, HS-ASA , ACS 14 Indomethacin: ATB-43

Sulindac Ibuprofen Naproxen
B

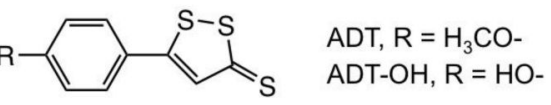<smiles>CCCCCC(=O)Oc1ccccc1C(=O)Oc1ccc(-c2cc(=S)ss2)cc1</smiles>

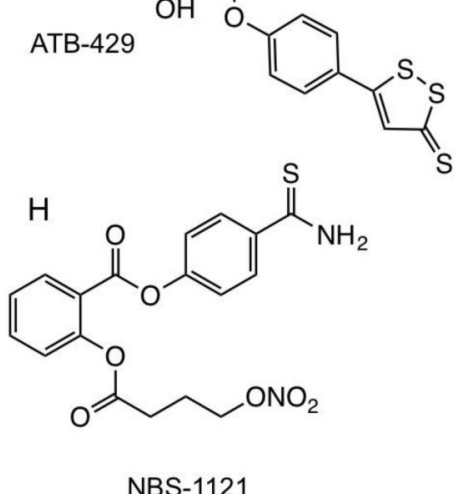

D<smiles>NC(=S)c1ccc(O)cc1</smiles><smiles>CC(C(=O)Oc1ccc(-c2cc(=S)ss2)cc1)c1ccc2cc(OC(=O)CCCO[N+](=O)[O-])ccc2c1</smiles>

AVT-219

NBS-1121

Figure 4.

Synthetic $\mathrm{H}_{2} \mathrm{~S}$-donating compounds. (A) GYY4137 a slow $\mathrm{H}_{2} \mathrm{~S}$ generating compound. (B) ADT (anethole dithiolethione); ADT-OH, (5-(4-hydroxyphenyl)-3H-1,2-dithiole-3-thione, releases $\mathrm{H}_{2} \mathrm{~S}$ ); (C) various $\mathrm{H}_{2} \mathrm{~S}$-donating NSAIDs; (D) TBZ (4-hydroxy benzothiazamide, releases $\mathrm{H}_{2} \mathrm{~S}$ ); (E) ATB-346, $\mathrm{H}_{2} \mathrm{~S}$-donating naproxen; (F) ATB-429, $\mathrm{H}_{2} \mathrm{~S}$-donating mesalamine; (G and H) NBS-1120 and NBS-1121, NOSH-aspirin, dual NO- and $\mathrm{H}_{2} \mathrm{~S}-$ donating hybrids of aspirin; (I) AVT-219, NOSH-naproxen, dual NO- and $\mathrm{H}_{2} \mathrm{~S}$-donating hybrid of naproxen; (J) 3-butyl-1,2-dithiolane, releases $\mathrm{H}_{2} \mathrm{~S}$. 
<smiles>O=C(CCCCCCCCC[P+](c1ccccc1)(c1ccccc1)c1ccccc1)Oc1ccc(-c2cc(=S)ss2)cc1</smiles><smiles>CCC(COC(=O)c1cc(OC)c(OC)c(OC)c1)(NC)c1ccccc1</smiles>

C

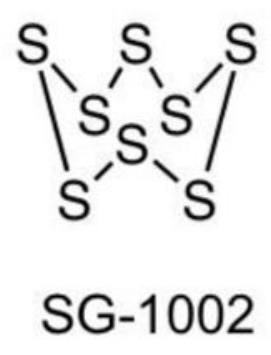

Figure 5.

(A) AP39, a mitochondrial-targeting $\mathrm{H}_{2} \mathrm{~S}$-donor; (B) GIC-1001, trimebutine salt; (C) SG-1002, polyvalent sulfur. 


\section{Table 1}

$\mathrm{H}_{2} \mathrm{~S}$-based therapeutics in development

\begin{tabular}{lll}
\hline Compound & Clinical indication / Derivative & Status \\
ATB-346 & Osteoarthritis / Naproxen & Phase-II \\
ATB-352 & Acute pain / Ketoprofen & Preclinical \\
ATB-340 & Thrombosis / Aspirin & Preclinical \\
ATB-429 & Ulcerative colitis / Mesalamine & Preclinical \\
NBS-1120 & Cancer, inflammation, pain / Aspirin & Preclinical \\
AVT-219 & Osteoarthritis, pain / Naproxen & Preclinical \\
GIC-1001 & Colonic pain / Trimebutine salt & Phase-II \\
SG-1001 & Oxidative stress, heart failure / Polyvalent sulfur & Phase-II ${ }^{\dagger}$ \\
GYY4137 & Cancer, inflammation, hypertension & Unknown \\
AP39 & Inflammation, oxidative stress & Preclinical \\
\hline$*$ \\
\hline
\end{tabular}

Biochem Pharmacol. Author manuscript; available in PMC 2019 March 01. 